\title{
Innleiðing jafnlaunakerfis hjá skipulagsheildum: Stuðningur, hindranir og næstu skref
}

\author{
Guðbjörg Ingunn Óskarsdóttir og Ragna Kemp Haraldsdóttir ${ }^{1}$
}

\begin{abstract}
Ágrip
Ísland er fyrsta pjóðin til að lögfesta jafnlaunastaðal en tilgangur hans er að koma á og viðhalda launajafnrétti kynja á vinnustað. Samkvæmt lögunum ber vinnustöðum að fá jafnlaunavottun að undangenginni úttekt. Markmið rannsóknarinnar var að kanna hvernig skipulagsheildir sem hlotið höfðu jafnlaunavottun hefðu staðið að innleiðingu jafnlaunakerfis í samræmi við kröfur jafnlaunastaðalsins. Tilgangurinn var að varpa ljósi á hvaða pættir reyndust styðja við innleiðingarferlið og hverjar væru helstu hindranir. Pá var kannað hvernig skipulagsheildum gekk að mæta auknum kröfum um skjalfestingu gagna samhliða innleiðingu. Rannsóknin byggist á eigindlegri aðferðafræði. Tekin voru tíu hálfstöðluð viðtöl, níu peirra við sérfræðinga innan sex skipulagsheilda og eitt við úttektaraðila. Pá var höfð til samanburðar textagreining á kröfum ÍST 85:2012 til skjalfestingar og erindum í 437. pingmáli um lögfestingu jafnlaunakerfis frá 146. löggjafarpingi 2017-2018. Niðurstöður benda til pess að innleiðing jafnlaunastaðals hafi styrkt annað gæðastarf og öfugt. Pannig virtust skipulagheildir sem pegar höfðu innleitt gæðastaðla og/eða unnu skilvirkt að skjalastjórn hafa forskot á aðrar. Styrkur peirra fólst í sérpekkingu starfsfólks á sviði mannauðsmála, gæðamála og skjalamála sem og formföstu umhverfi sem var vel undirbúið fyrir innleiðingu gæðastaðals. Мeð innleiðingu jafnlaunakerfis komust á agaðri vinnubrögð og aukið gagnsæi í launasetningu. Skjalfesting ýmissa mannauðsgagna jókst í samræmi við kröfur jafnlaunastaðals. Niðurstöður leiddu einnig í ljós að helstu hindranir við innleiðingu voru tímaskortur og aukið vinnuálag. Starfaflokkun reyndist að auki tímafrek og var ekki studd af íslenskri starfaflokkun ÍSTARF95. Pá komu fram gagnrýnisraddir sem beindust að lögleiðingu jafnlaunastaðals almennt sem og að eftirlitsaðilum sem skorti fjármagn og mannafla til að sinna lögbundnu hlutverki sínu. Рað er áhyggjuefni pví að fjölmargir vinnustaðir eiga eftir að innleiða staðalinn fyrir lok árs 2022.
\end{abstract}

\section{Abstract}

Iceland is the first country to legislate an Equal Pay Standard (EPS), which is intended to establish and maintain gender pay equality in the workplace. The law requires employers to obtain equal pay certification following an audit. The purpose of the research was to explain what steps EPS certified organizations had taken to implement the standard. It also casts light on which factors support the imple-

1 Guðbjörg Ingunn Óskarsdóttir er sérfræðingur í upplýsinga- og skjalastjórn hjá forsætisráðuneytinu. Netfang: gudbjorg.ingunn.oskarsdottir@for.is. Ragna Kemp Haraldsdóttir er lektor í upplýsingafræði við Háskóla Íslands. Netfang: rh@hi.is.

This work is licensed under a Creative Commons Attribution 4.0 License.

DOI: https://doi.org/10.24122/tve.a.2021.18.1.2 
mentation process and what obstacles were encountered. Also, to explore how organizations come across increased systematic information and records management alongside the implementation. The research is based on qualitative methodology containing ten semi-structured interviews, nine within different organizations and one in an accredited certification body. It also contains a documentary analysis of the registration requirements of the EPS and reviews sent to the Icelandic Parliament on bill no. 437 in 2017. The results imply that the implementation of the EPS has supported other quality improvement and vice versa. Organizations that had already implemented quality standards and/or systematic records management had a definite advantage. Their strength lay in the expertise of staff in the field of human resources, quality and record management and they had well-established and prepared work environment. With the implementation of EPS, disciplined working methods and increased transparency in wage setting were established. Documentation of data regarding human resources increased in accordance with the requirements of EPS. The research also indicates that lack of time and added pressure due to additional workload were an obstacle in the implementation process. Job classification and wage analysis was laborious due to unclear standards for classification of occupations. Documentary analysis revealed criticism towards the EPS legislation and monitoring institutions that were considered understaffed and underfinanced. This is a matter of concern, as many organizations must implement the standard before the end of 2022.

JEL flokkun: D63; J16; J30; J71; L15; M10; M52

Lykilorð: Jafnlaunastaðall, gæðastjórnun, upplýsinga- og skjalastjórn, innleiðing, lögbundnir eftirlitsaðilar.

Keywords: Equal Pay Standard, Quality Management, Information and Records Management, Implementation, Monitoring Institutions.

\section{The Implementation of an Equal Pay Management System in Organizations: Support, Obstacles and Prospects}

\section{Inngangur}

Ísland er fyrsta pjóðin til að lögfesta jafnlaunastaðal og krefja skipulagsheildir um vottun pess efnis að staðallinn hafi verið innleiddur og hefur fengið töluverða athygli fyrir pá vegferð (Sigmarsdottir, 2018; Haraldsdottir, 2020; Burri, 2019; Gerða Björg Hafsteinsdóttir o.fl., 2020; Wagner, 2020). Markmið jafnlaunavottunar er að draga úr kynbundnum launamun, bæta sýn stjórnenda á mannauðsmál og auðvelda peim starfsmannahald og rökstuðning við launasetningu. Pannig er stuðlað að gagnsærra og réttlátara launakerfi (Stjórnarrád Íslands, e.d.a).

Um 1.180 skipulagsheildum par sem starfa um 147.000 einstaklingar er gert skylt að innleiða jafnlaunastaðal sem er um 80\% af íslenskum vinnumarkaði (Stjórnarráð Íslands, e.d.a). Mismunandi tímamörk gilda um hvenær vottunarferli skuli lokið. Upphaflega var gert ráð fyrir að í árslok 2021 yrðu allar skipulagsheildir sem lögin ná til komnar með vottun. Framvindan hefur hins vegar verið hæg. Aðeins 15 af 142 skipulagsheildum sem lögum samkvæmt hefðu átt að vera vottaðar fyrir árslok 2018 voru pá komnar með vottun (Stjórnarráð Íslands, 2018). Undir lok árs 2018 var fresturinn framlengdur til ársloka 2022 par sem skortur var á úttektaraðilum til að mæta eftirspurn. Í upphafi árs 2020 var tilkynnt að einungis 134 skipulagsheildir af 269 sem áttu að vera komnar með vottun fyrir árslok 2019 stóðust tímamörk (Stjórnarráð Íslands, 2020). Fram hefur komið að fyrirtæki og stofnanir vanmátu tímann sem tók að setja upp jafnlaunakerfi sem olli töfum á innleiðingarferlinu (Forsætisráðuneytið, 2020). 
Fjölmargir aðilar eru enn án vottunar, p.m.t. sveitarfélög sem starfa án fullgildrar jafnréttisáætlunar (Morgunblaðið, 2019). Sum sveitarfélög telja sig ekki purfa að setja sér jafnréttisáætlun og/eða hafa ekki brugðist við erindi Jafnréttisstofu um málið (Ómar Friðriksson, 2019). Í viðtali við framkvæmdastjóra Jafnréttisstofu kom fram að ákveðinn „flöskuháls" hefði myndast vegna skorts á vottunarstofum sem gæti verið ein ástæðan fyrir hægum framgangi (Ragnhildur Prastardóttir, 2019). Jafnréttisstofa hefur eftirlitshlutverk og getur krafið skipulagsheildir um að framfylgja lögunum og gera viðunandi úrbætur innan hæfilegs frests, að viðlögðum dagsektum. Samkvæmt upplýsingum frá stofnuninni hefur sektarákvæði ekki verið beitt til pessa (Jón Fannar Kolbeinsson, munnleg heimild, 15. júní 2021). Par sem beiting dagsekta telst ípyngjandi stjórnvaldsákvörðun hefur Jafnréttisstofa ákveðið að vinna út frá meðalhófsreglu stjórnsýsluréttar sem segir að ekki skuli ganga lengra en nauðsyn krefur (Jón Fannar Kolbeinsson, munnleg heimild, 7. febrúar 2020). Samkvæmt lista sem Jafnréttisstofa gefur út og uppfærður var 14. júní 2021 hafa nú alls 308 skipulagsheildir hlotið vottun (Jafnréttisstofa, 2021). Síðustu níu mánuði hafa pví ríflega átta skipulagsheildir fengið jafnlaunavottun á mánuði að meðaltali².

Í greininni er fjallað um innleiðingarferli jafnlaunastaðals hjá skipulagsheildum sem pegar hafa hlotið jafnlaunavottun. Skoðað verður annars vegar hvaða pættir póttu styðja við innleiðingarferli jafnlaunavottunar og hins vegar er horft til helstu hindrana sem komu upp við innleiðinguna. Í jafnlaunastaðli koma fram ítarlegar kröfur um stýringu skjala og skráa par sem skilgreina parf og skjalfesta allt umfang jafnlaunakerfisins sem nær til alls starfsfólks viðkomandi skipulagsheildar (ÍST 85:2012, 2012; Haraldsdottir, 2020). Pessar kröfur hafa sætt nokkurri gagnrýni og pá helst fyrir aukið skrifræði og kerfisvæðingu (Gerða Björg Hafsteinsdóttir o.fl., 2020). Pví er áhugavert að skoða sérstaklega pann pátt innleiðingarferlisins sem snýr að skjalfestingu gagna. Eftirfarandi rannsóknarspurningar eru settar fram:

1. Hvaða pættir skipta máli til að innleiðing jafnlaunastaðals gangi vel og hverjar eru helstu hindranir?

2. Hvaða leiðir voru farnar til að uppfylla skilyrði jafnlaunastaðals um skjalfestingu?

Greinin skiptist í fjóra meginkafla auk inngangs. Fyrst er fræðilegum bakgrunni lýst og greint frá íslenskum og erlendum rannsóknum sem tengjast viðfangsefninu. Sagt er stuttlega frá lögfestingu jafnlaunastaðals í samhengi við stöðu jafnréttis á Íslandi sem og frá efnistökum og kröfum staðalsins. Pá er rætt um fræðilegar forsendur og samspil upplýsinga- og skjalastjórnar og gæðastjórnunar. Einnig er fjallað um pekkingarstjórnun en sú fræðigrein tekur á skipulagi pekkingar sem í pessu samhengi skiptir máli vegna krafna jafnlaunastaðals um skráningu menntunar og hæfni til sönnunar forsendna launaákvarðana. Pví næst er aðferðafræði rannsóknarinnar gerð skil. Pá er farið yfir helstu niðurstöður út frá meginpemum rannsóknarinnar sem byggjast á samvinnu og skipulagi, álagi og ávinningi og fyrirliggjandi gögnum. Loks er í umræðum og samantekt fléttað saman fræðilegum forsendum og helstu niðurstöðum og velt vöngum yfir mögulegum framtíðarrannsóknum.

\section{Fræðilegur bakgrunnur}

Ísland mælist hæst á lista Alpjóðaefnahagsráðsins um kynjajafnrétti 2021, tólfta árið í röð, með 89,2 stig (World Economic Forum, 2021; Stjórnarráð Íslands, 2021a). Íslandi hefur jafnvel verið lýst sem fremsta kvenréttindaland veraldar [e. the world's most feminist country] með fyrsta lýðræðislega kjörna kvenkyns forseta í heimi, frú Vigdísi Finnbogadóttur, árið 1980 og fyrsta opinberlega samkynhneigða kvenkyns forsætisráðherra heims, Jóhönnu Sigurðardóttur (Bindel, 2010). Í kjölfar skýrslu Alpjóðaefnahagsráđsins sem kom

2 Hinn 9. september 2020 höfðu 235 skipulagsheildir hlotið vottun. Peim hefur pví fjölgað um 73 á níu mánuðum eða um rúmlega átta á mánuði. 
út í mars á pessu ári var haft eftir Katrínu Jakobsdóttur forsætisráðherra: „एాað eru auðvitað bara gleðitíðindi að við mælumst parna efst enn og aftur en pað segir ekki endilega að kynjajafnrétti sé náð“ (Porvaldur S. Helgason, 2021). Gagnrýnendur telja landið pó enga kvenréttindaparadís. Á Íslandi eru jafnréttismál iðulega talin í góðum farvegi í samanburði við önnur lönd (Lindahl, 2019). Eigi síður hallar enn á konur (Annadís Rúdólfsdóttir og Ásta Jóhannesdóttir, 2018; Katrín Ólafsdóttir, 2018; Wagner, 2020). Í meistararitgerð Guðbjargar I. Óskarsdóttur (2019) er bent á að jafnlaunastaðallinn taki til að mynda ekki á ólíkum launum starfsstétta en vitað er að hefðbundin karlastörf eru betur launuð en hefðbundin kvennastörf. Að auki vinna konur oftar hlutastörf og styttri vinnudag en karlar. Íslenskar rannsóknir hafa dregið fram að petta endurspegli kynbundið valdaójafnvægi og ábyrgð sem konur bera á fjölskyldum umfram karla (Katrín Ólafsdóttir og Steinunn Rögnvaldsdóttir, 2015; Ólöf Júlíusdóttir o.fl., 2018). Prátt fyrir fjölda aðgerða sem miða að auknu jafnrétti eru fáar konur æðstu stjórnendur í íslensku viðskiptalífi (Ólöf Júlíusdóttir, 2019). Rannsóknir sýna að konur eru í minnihluta í ábyrgðarstörfum og axla meiri fjölskylduábyrgð en karlar hvað varðar umönnun barna, veikra og peirra sem eldri eru sem og umsjón heimilis (Ólöf Júlíusdóttir o.fl., 2018; Einarsdóttir, 2020). Pá gegndi engin kona stöðu forstjóra í skráðu félagi 2019 og aðeins örfáar konur áttu sæti í framkvæmdastjórnum slíkra félaga (Ásta Dís Oladóttir o.fl., 2019). Ný rannsókn Póru H. Christiansen o.fl. (2021) sýnir að í 19 skráðum félögum var engin kona forstjóri, prátt fyrir að um slík félög gildi leiðbeiningar um góða stjórnarhætti sem Viðskiptaráð, Samtök atvinnulífsins og Nasdaq gefa út. Hinn 1. júlí 2021 taka gildi nýjar leiðbeiningar par sem í fyrsta sinn er „kveðið á um að stjórnir skuli setja stefnu um fjölbreytileika í tengslum við stjórn, framkvæmdastjórn og æðstu stjórnendur (Viðskiptaráð o.fl., 2021). Rannsókn Hagstofunnar á launamun kynjanna 2008-2016 leiddi í ljós að konur voru að meðaltali með 4,8\% lægri laun en karlar pegar tekið hafði verið mið af páttum sem lagðir eru til grundvallar greiningunni eins og tegund starfa, menntun og vinnutíma. Skýrður launamunur var hins vegar 7,4\%. Bæði skýrður og óútskýrður launamunur dróst saman á tímabilinu (Hagstofa Íslands, 2018). Samt sem áður eru konur í miklum meirihluta pegar kemur að háskólamenntun en frá aldamótum hafa nær tvöfalt fleiri konur en karlar útskrifast með háskólagráðu (Hagstofa Íslands, 2020).

\subsection{Jafnlaunastaðall}

Innleiðing jafnlaunakerfis samkvæmt staðli ÍST 85:2012 var lögfest með lögum nr. 56/2017, um breytingu á lögum um jafna stöðu og jafnan rétt kvenna og karla, sem tóku gildi 1. janúar 2018 (Lög um breytingar á lögum um jafna stöðu og jafnan rétt kvenna og karla nr. 10, 2008). Innleiðing og lögfestingu jafnlaunavottunar var ætlað að tryggja fagleg vinnubrögð við launasetningu (Burri, 2019; Stjórnarráð Íslands, e.d.a). Jafnlaunastaðallinn var hins vegar fyrst gefinn út árið 2012 og var pá valkvæður. Markmið jafnlaunavottunar var að draga úr kynbundnum launamun, auka starfsánægju og traust starfsfólks á að faglega væri staðið að launasetningu. Staðallinn var í upphafi verkfæri sem nýtast átti öllum fyrirtækjum og stofnunum óháð stærð, starfsemi, hlutverki og kynjahlutfalli (ÍST 85:2012, 2012). Áður en staðallinn var lögfestur stóð skipulagsheildum til boða að kanna kynbundinn launamun í gegnum jafnlaunavottun VR eða í gegnum jafnlaunaúttekt PwC á Íslandi (e. PricewaterhouseCoopers). Fyrirtækjaráðgjöf PwC bauð upp á jafnlaunaúttekt frá árinu 2010 sem veitti greiningu á stöðu launamála eftir kyni. Skipulagsheildir sem mældust með 3,5\% launamun eða minna hlutu gullmerki PwC sem litið var á sem „forskot í samkeppni um starfsfólk [sem hefði] jákvæð áhrif á ímynd og orðspor fyrirtækisins" (PwC, e.d.). Árið 2012 hóf VR jafnlaunavottun sem byggðist á og uppfyllti jafnlaunastaðal ÍST 85:2012. VR fékk faggilta vottunarstofu BSI (e. British Standard Institution) til samstarfs til pess að sjá um úttektir. Tæplega 30 skipulagsheildir hlutu jafnlaunavottun VR (Ingibjörg Hrund Práinsdóttir, munnleg heimild, 13. ágúst 2018). Eftir að jafnlaunastaðallinn var lögfestur hefur VR hætt jafnlaunavottun (VR, e.d.). 
Pátttakendur tilraunaverkefnis um innleiðingu jafnlaunastaðals á vegum aðgerðahóps stjórnvalda og aðila vinnumarkaðsins létu reyna á jafnlaunastaðal árið 2012. Einn pessara aðila var tollstjóraembættið en par hélt mannauðsstjórinn pví fram að „innleiðing jafnlaunastaðals hafi verið dæmigerð gæðastjórnun" sem fól í sér að til að fylgja kröfum staðalsins væri nauðsynlegt að nýta skilgreindar aðferðir gæðastjórnunar (Unnur Ýr Kristjánsdóttir, 2017). Sérfræðingur hjá velferðarráðuneytinu sem fylgdi ferlinu eftir sagði að „tilraunverkefnið opnaði augu fólks" par sem niðurstöðurnar voru aðrar en gert hafði verið ráð fyrir. Pannig vildi enginn stjórnandi mismuna starfsfólki í launum en grundvöllur launasetningar væri pannig uppbyggður að mismunum gæti átt sér stað. •að væri hluti af "ómeðvitaðri kynjahlutdrægni“ (Chalaby, 2017). Pátttakendur tilraunaverkefnisins voru sammála um að innleiðing jafnlaunastaðals gæfi betri sýn á launamál viðkomandi skipulagsheildar, ákvarðanir yrðu gagnsærri og málefnalegri og aukin vitund í jafnréttismálum. Tímalengd innleiðingar fór eftir stöðu skipulagsheilda í mannauðs- og gæðamálum (Velferðarráðuneytið, 2018). Í maí 2019 birti forsætisráðuneytið niðurstöður könnunar um innleiðingu jafnlaunastaðals par sem fram kom að jafnlaunavottun gat haft jákvæð áhrif á starfsánægju, leitt til betra skipulags í mannauðsmálum og aukið vitund um jafnrétti. Pess utan töldu stjórnendur að peir hefðu bætt eigin yfirsýn og skilvirkni í rekstri og ákvörðun launa. Helstu áskoranir við innleiðingu reyndust vera flokkun starfa, gerð verklagsreglna, tímaskortur og vottunarferli. Kostnaður reyndist ekki mjög ípyngjandi páttur (Stjórnarráð Íslands, 2019). Í árslok 2020 sendi ráđuneytið út aðra könnun sem leiddi í ljós að helsti ávinningur við innleiðingu jafnlaunastaðals væri betra skipulag við launasetningu. Rúmur helmingur svarenda taldi innleiðinguna hafa aukið gagnsæi pegar kemur að launaákvörðunum og rúm $70 \%$ að traust starfsfólks til málefnalegrar launasetningar væri bættara með innleiðingu staðalsins (Stjórnarráð Íslands, 2021b) Kannanirnar kallast á við niðurstöður Wagners (2018) sem gefa til kynna að prátt fyrir ípyngjandi innleiðingarferli reyndist sá ávinningur sem hlaust af jafnlaunavottun vega pyngra. Jákvæðra áhrifa gætti á ráðningarferli og launakerfið varð gagnsærra og betur skipulagt. Aukinnar jafnréttisvitundar gætti innan skipulagsheilda og trú starfsfólks á jafnrétti innan vinnustaðarins jókst. Nýleg rannsókn Wagners gefur til kynna að við jafnlaunavottun flytjist sönnunarbyrði á forsendum launasetningar frá launpega til launagreiðanda par sem jafnlaunakerfið feli í sér innra eftirlit og endurskoðun frá priðja aðila [Jafnréttisstofu] sem hafi möguleika á að beita dagsektum ef lögbundinni skyldu er ekki framfylgt (Wagner, 2020). Pessar aðgerðir geti stuðlað að kynjajafnrétti með auknu aðgengi að upplýsingum fyrir launpega [og pá sem leita að vinnu] par sem pær gerðu aðila [stjórnendur] ábyrga fyrir ákvörðunum sínum (Wagner, 2020).

Jafnlaunastaðall er byggður upp að fyrirmynd alpjóðlegra staðla líkt og gæðastjórnunarstaðallinn ISO 9001 og umhverfisstjórnunarstaðallinn ISO 14001 (Stjórnarráð Íslands, e.d.b). Alpjóðlegu stjórnunarstaðlarnir eru vel pekktir hérlendis en peir eru taldir veita aðgengi að nýjum mörkuðum og tryggingu fyrir gæðum, auðvelda áhættustjórnun og styðja hlítingu laga og reglna (Staðlaráð Íslands, 2020). Uppbygging jafnlaunastaðals er hefðbundin. Fjallað er um umfang en honum er ætlað að ná til allrar starfsemi viðkomandi vinnustaðar og pví ekki hægt að fá vottun á hluta af heild. Ýmsar kröfur eru settar á skipulagsheildir við innleiðingu jafnlaunastaðals. Skipulagsheildum er pannig gert að skilgreina jafnlaunastefnu, fá sampykkta skriflega jafnréttisáætlun ásamt framkvæmdaáætlun í jafnréttismálum, framkvæma starfaflokkun par sem starfslýsingar fylgja hverju starfi og gera launagreiningu áður en kemur að fyrstu vottun. Til hliðsjónar við launagreiningu skal halda skrá yfir menntun og hæfni starfsfólks. Bera parf kennsl á lagalegar kröfur og aðrar kröfur sem geta verið ólíkar eftir starfsemi. Gerð er krafa um að skipulagsheildir starfræki jafnlaunakerfið en í pví felst að tryggja auðlindir, hæfni, pjálfun og vitund sem parf til að kerfið virki. Pannig er gerð krafa um vöktun jafnlaunakerfisins, mælingu á árangri, mat á hlítingu [laga] sem og greiningu á frábrigðum, úrbótum og forvörnum. Að síðustu er krafa gerð um stýringu skráa, innri úttekt og rýni stjórnenda (ÍST 85:2012, 2012). 
Auk pess er í staðlinum gerð krafa um að skipulagsheildir skjalfesti, viðhaldi og stuðli að stöðugum umbótum á stjórnun pess jafnlaunakerfis sem innleitt hefur verið. Staðallinn gerir skýra kröfu að „,allar ákvarðanir um laun og kjör séu skjalfestar, rökstuddar og rekjanlegar" (ÍST 85:2012, 2012, bls. 7). Pegar skoðaðir eru kaflar 4.4.4, 4.4.5 og 4.5.4 í jafnlaunastaðli má sjá hve skjalfestingin er veigamikill páttur (ÍST 85:2012, 2012; Haraldsdottir og Gunnlaugsdottir, 2018). Par kemur fram að mikilvægt er að halda skrá yfir pá pætti sem hafa áhrif á kjör starfsfólks, svo sem upplýsingar um formlega menntun, viðbótarmenntun og/eða sérhæfingu, starfsreynslu og aðra persónubundna pætti sem taldir eru til við launasetningu (ÍST 85:2012, 2012). Auk pess er samkvæmt jafnlaunakerfinu ekki hægt að launaraða samkvæmt menntun ef ekki eru tiltæk skjöl henni til staðfestingar. Slík skráning er pví lykilpáttur í að uppfylla kröfur jafnlaunastaðals (Haraldsdottir og Gunnlaugsdottir, 2018). Rannsókn Jóhönnu Rósu Arnardóttur og Jóns Torfa Jónassonar (2004) sýndi fram á að menntun og laun væru að öllu jöfnu vel tengd. Pó sýna niðurstöður nýlegrar könnunar frá Stjórnarráðinu á próun ráðstöfunartekna, eigna og skulda landsmanna að heildartekjur kvenna með BS-gráðu eru sambærilegar heildartekjum karla með grunnmenntun (Stjórnarrád Íslands, 2021c).

Ný heildarlög um jafna stöðu og jafnan rétt kynjanna, nr. 150/2020, tóku gildi 6. janúar 2021. Í 1. gr. er markmiðum peirra lýst en peim er ætlað að „koma í veg fyrir mismunun á grundvelli kyns og koma á og viðhalda jafnrétti og jöfnum tækifærum kynjanna á öllum sviðum samfélagsins“. Lögunum er ætlað að „vinna gegn launamisrétti og annarri mismunun á grundvelli kyns á vinnumarkaði, m.a. með pví að fyrirtæki og stofnanir uppfylli skilyrði jafnlaunavottunar eða jafnlaunastaðfestingar“" (Lög nr. 150, 2020). Ný lög fela í sér umtalsverðar breytingar á forsendum jafnlaunavottunar pví nú hafa fyrirtæki og stofnanir par sem 25-49 einstaklingar starfa að jafnaði val um að undirgangast jafnlaunavottun, eins og lýst hefur verið hér að framan, eða öðlast jafnlaunastaðfestingu.

Með jafnlaunastaðfestingu staðfestir Jafnréttisstofa að viðkomandi skipulagsheild hafi skilað gögnum sem sýna fram á með fullnægjandi hætti að jafnlaunakerfi og framkvæmd pess mismuni ekki í launum á grundvelli kyns. Pessi gögn eru: Stefna skipulagsheildar í jafnlaunamálum, jafnréttisáætlun eða sampætting jafnréttissjónarmiða í starfsmannastefnu; starfaflokkun par sem lagt er mat á ábyrgð, álag, hæfni og vinnuaðstæður pannig að saman flokkist sömu eða jafnverðmæt störf; launagreining sem byggist á starfaflokkun og sýnir meðaltal fastra mánaðarlauna fyrir dagvinnu, fastar viðbótargreiðslur fyrir störf og allar aukagreiðslur eftir kynjum; áætlun um úrbætur og loks samantekt æðsta stjórnanda um niðurstöður gagna (Lög um jafna stöðu og jafnan rétt kynjanna nr. 150, 2020). Opinberir aðilar, sjóðir og fyrirtæki sem eru að hálfu eða meiri hluta í eigu ríkisins skulu hins vegar öðlast jafnlaunavottun skv. 7. gr. laganna. Pá skulu pau fyrirtæki og stofnanir sem áttu að öðlast jafnlaunavottun fyrir 31. desember 2019, en hafa ekki uppfyllt pá lagaskyldu, framfylgja fyrri lagaskyldu og geta pví ekki óskað eftir jafnlaunastaðfestingu. Tólf umsagnir bárust um frumvarp til nýrra heildarlaga um jafnan rétt og jafna stöðu kynjanna.

Jafnlaunastaðall er ekki yfir gagnrýni hafinn. Samkvæmt Samtökum atvinnulífsins (SA) var pað aldrei markmiðið við gerð staðalsins að hann yrði lögfestur enda segir í inngangi hans að hann sé „valkvæður“. Pá beinist gagnrýni SA að pví að smærri skipulagsheildir eigi erfitt með að innleiða staðalinn par sem pær skorti fjármagn, mannauð og sérpekkingu til verkefnisins (Halldór Benjamín Porbergsson, 2017). Pessi gagnrýni endurspeglast í niðurstöðum könnunar forsætisráðuneytisins frá 2019 par sem fram komu athugasemdir um að sumar kröfur staðalsins væru of miklar og verkfæri hans of flókin fyrir lítil fyrirtæki (Stjórnarráð Íslands, 2019). Gagnrýni hefur einnig beinst að eftirlitsaðilum sem gætu átt í erfiðleikum með að framfylgja löggjöfinni vegna fjárskorts og fámennis. Jafnréttisstofa var í pessu sambandi sögð vera „fjársvelt, fámenn, kvenlæg, afskekkt og [með] fá úrræði á valdi sínu“. Hún hafi pví ekki bolmagn til að sinna verkefninu. Í jafnréttisráði komu fram ólíkar skoðanir um mátt Jafnréttisstofu. Sumir töldu stofuna "tannlausa“ par sem hún gæti ekki beitt refsiheimildum gegn peim sem brjóta lög um kynjakvóta í stjórnum, en 
aðrir segja hana öfluga en geta orðið enn öflugri með auknu fjármagni og meiri mannafla (Arnhildur Hálfdánardóttir, 2015). Pessi gagnrýni á mögulega rót sína að rekja til fyrri reynslu Íslendinga af eftirlitsstofnunum og vanmætti peirra í tengslum við efnahagshrunið 2008 (Benediktsdottir o.fl., 2011). Pá hefur gagnrýni beinst að faggiltum vottunarstofum en viðvarandi skortur á aðilum til að votta jafnlaunastaðal hefur valdið töfum par sem einungis tvær stofur uppfylltu skilyrði til vottunar í upphafi og höfðu pá tímabundin starfsleyfi og litla reynslu enda staðallinn nýr af nálinni (Ólafur Stephensen, 2017). Um mitt ár 2019 var fjöldi vottunaraðila enn gagnrýndur. Pá áttu 223 skipulagsheildir enn eftir að öðlast vottun á árinu og vottunaraðilar voru orðnir fjórir. Ástandinu var líkt við að allir bifreiðaeigendur mættu á sama tíma með bíla sína í skoðun. Fjölga pyrfti vottunaraðilum að mati Porgerðar Katrínar Gunnarsdóttur pingmanns sem sagði að viðmælendur hennar víðs vegar úr atvinnulífinu hefðu tekið fram að jafnlaunavottun „hafi svo jákvæð áhrif almennt inn í fyrirtækin á svo mörgum öðrum sviðum en eingöngu sviði jafnréttismála. Petta er tæki sem nær yfir meira svið heldur en eingöngu hreina og klára jafnlaunavottun“ (Birna Dröfn Jónasdóttir o.fl., 2019). Helgi Tómasson (2017) taldi hins vegar að lögfesting jafnlaunastaðals hefði í för með sér ",pungar skriffinnskuálögur“ á mörg fyrirtæki. Sambærileg gagnrýni kom fram í grein Gerðu Bjargar Hafsteinsdóttur o.fl. (2020) um upplifun stjórnenda á áhrifum jafnlaunavottunar á kjaraumhverfi. Gagnrýni var beint að aukinni skrifvæðingu [kerfisvæðingu] sem fól í sér víðtækari og ítarlegri skráningu á gögnum en áður hafði verið, tilfærslu á ákvörðunarvaldi stjórnenda par sem sumir viðmælenda héldu pví fram að í raun væru pað vottunaraðilar sem færu með ákvörðunarvaldið. Að auki væri jafnlaunavottun tálsýn par sem aðilar hefðu í raun frjálsar hendur varðandi útfærslur viðmiða og gætu pví hagrætt niðurstöðum ef vilji væri fyrir hendi. Pessi tálsýn byggðist einnig á peirri upplifun viðmælenda að ekki væru ávallt sömu forsendur fyrir útreikningum launa. Pá póttu vottunaraðilar ekki vinna samræmt að úttekt jafnlaunakerfa og í einhverjum tilfellum var upplifun viðmælenda í rannsókninni sú að jafnlaunakerfið væri vottað kerfisins vegna en ekki samkvæmt markmiðum jafnlaunastaðals (Gerða Björg Hafsteinsdóttir o.fl., 2020). Ípyngjandi kvaðir eru áfram gagnrýndar í athugasemdum SA á lögum um jafnan rétt og jafna stöðu kynjanna í 126. pingmáli 2020 en par er fjallað um kröfur um stöðug skýrsluskil fyrirtækja og stofnana til Jafnréttisstofu í tengslum við jafnréttisstaðfestingu (Heiðrún Björk Gísladóttir, 2020). Í athugasemdum frá Jafnréttisstofu vegna pessa pingmáls kemur fram sú ábending að umfang verkefnisins [jafnlaunastaðfestingar] feli í sér ákveðinn „ómöguleika“ við að afgreiða allar skipulagsheildir sem ber skylda til að verða sér úti um staðfestingu innan tilskilins frests. Pá er ítrekuð nauðsyn pess að tryggja fjármögnun verkefnisins (Katrín Björg Ríkharðsdóttir og Jón Fannar Kolbeinsson, 2020).

\subsection{Stuðningur og hindranir við innleiðingu gæðakerfa}

Með gæðastjórnun er lögð áhersla á að mæla og stjórna ferlum til að hægt sé að vinna að stöðugum umbótum (Kerzner, 2009). •að getur reynst flókið ferli að innleiða gæðakerfi en pó má segja að gæðakerfi byggist á einfaldri hugmynd: „Skjalfestu pað sem pú ætlar að framkvæma, gerðu pað sem pú skjalfestir" (Jóhanna Gunnlaugsdóttir, 2003, bls. 43). Líkt og með alpjóðlega gæðastaðla byggist jafnlaunastaðallinn á aðferðafræðinni „Plan, Do, Check, Act" sem útleggst á íslensku sem skipuleggja, gera, gáta (vakta og mæla) og loks grípa til aðgerða (Staðlaráð Íslands, 2020; Helgi Pór Ingason, 2015). Rannsóknir hafa sýnt fram á nokkra lykilpætti sem pykja styðja við innleiðingu gæðakerfis. Meðal pessara pátta er stuðningur stjórnenda, aðkoma utanaðkomandi ráðgjafa með sérhæfingu á sviðinu, markviss kynning á verkáætlunum, gerð verkferla, notkun upplýsingastjórnunarkerfa og pjálfun starfsfólks (Bell og Omachonu, 2011; Boiral, 2011; Bhuiyan og Alam, 2005; Jóhanna Gunnlaugsdóttir, 2010).

Gæðastjórnun er talin auka ánægju starfsfólks par sem hún hvetji til virkrar pátttöku (Tarí, Molina-Azorín og Heras, 2012; Helgi Pór Ingason, 2015). Niðurstöður rannsóknar 
Lin og Jang (2008) á innleiðingu ISO 9000 gæðastaðla bentu jafnframt til pess að hvatar að baki innleiðingar staðla séu lykilpáttur farsællar innleiðingar. Pannig geti innleiðingin verið drifin áfram af peim ávinningi sem hugsanleg vottun hefur í för með sér, svo sem alpjóðlega viðurkenningu, gagnsæi, rekjanleika ákvarðana, aukna samkeppnishæfni, samhæfð vinnubrögð, skilvirkari áhættustjórnun og aukið traust (Staðlaráð Íslands, 2020). Rannsóknir hafa einnig sýnt fram á að pað hefur jákvæð áhrif á innleiðingarferli nýrra staðla að laga gæðakerfið að peim ferlum sem pegar eru til staðar (Ivanova o.fl., 2014; Kakouris og Sfakianaki, 2019; Kim o.fl., 2011). Рað getur verið kostur við innleiðingu að hafa kerfið eins einfalt og mögulegt er og samnýta vinnubrögð með öðrum stöðlum (Boiral, 2011). Skipulagsheildir geta uppskorið mikilvægan ávinning við innleiðingu gæðastaðla, t.d. agað starfsumhverfi, aukna gæðavitund og skilvirka upplýsinga- og skjalastjórn (Bhuiyan og Alam, 2005). Einn helsti afrakstur innleiðingar gæðastaðla er fólginn í umbótum á kerfum, stöðluðum verkferlum og umhverfi sem styður við pekkingaröflun og samskipti. Nauðsynlegur stuðningur slíkrar innleiðingar felur í sér virka forystu, pjálfun og pátttöku alls starfsfólks og tryggingu pess að nauðsynleg aðföng séu til staðar til innleiðingarinnar (Kim o.fl., 2011).

Gæðaskjöl (e. document) gæðakerfa eru skjalfestar aðferðir, svo sem stefnur, leiðbeiningar, verklagsreglur, gátlistar, áætlanir og fleira sem sýnir hvað gert er ráð fyrir að skipulagsheildin geri og hvernig. Stýringin felur í sér að skjöl eru sampykkt, rýnd og uppfærð pannig að allar breytingar séu auðkenndar, að rétt notkun og læsileiki sé tryggður og að komið sé í veg fyrir notkun úreltra skjala. Pessar kröfur um gæðaskjöl eiga allir gæðastaðlar sameiginlega. Skrár (e. record) samkvæmt skilgreiningu gæðastjórnunar eru ein tegund skjala sem sýna fram á að tilgreindum árangri eða aðgerð hafi verið náð (ÍST 85:2012, 2012). Pau eru pannig til sönnunar um atburð eða aðgerð sem er lokið og oft staðfest með undirskrift eða formlegu sampykki. Dæmi um skrár sem tengjast jafnlaunastaðli eru fundargerðir, útfyllt eyðublöð, t.d. starfslýsingar, ráðningarsamningar, afrit af prófskírteinum starfsfólks, rótargreining frávika sem koma upp við vottun, pjálfunarskrá, skrá um hlítingu laga, gögn af upplýsingafundum stjórnenda, viðbrögð við erindum starfsfólks og svo mætti áfram telja.

Bæði innlendar og erlendar rannsóknir hafa bent til pess að krafan um skjalfestingu sé ein erfiðasta hindrunin sem flestar skipulagsheildir standa frammi fyrir í vottunarferlinu (Al-Rawahi og Bashir, 2011; Bell og Omachonu, 2011; Brumm, 1996; Jóhanna Gunnlaugsdóttir, 2003; Lemieux, 1996; Staðlaráð Íslands, 2008). Pað á sérstaklega við hjá litlum fyrirtækjum par sem oft er óformlegra starfsumhverfi (Staðlaráð Íslands, 2008). Rannsóknir hafa einnig sýnt fram á að ein helsta hindrun við innleiðingu gæðastaðla er ófullnægjandi stuðningur æðstu stjórnenda (Al-Rawahi og Bashir, 2011; Bhuiyan og Alam, 2005; Lin og Jang, 2008). Í rannsókn Bhuiyan og Alam (2005) kom fram að ónægar bjargir, tímaskortur og skortur á pjálfun starfsfólks gat virkað sem hindrun og að stærri skipulagheildir fundu síður fyrir erfiðleikum við innleiðingu en pær minni par sem pær höfðu betri bjargir. Rannsóknir hafa sýnt fram á að stærð skipulagsheilda hefur áhrif á innleiðingarferlið par sem stærri og meðalstórar skipulagsheildir eru líklegri til að öðlast vottun en litlar skipulagsheildir (Helgi Pór Ingason, 2015). Pannig getur takmarkað fjármagn, mannauður og bjargir haft pau áhrif að erfiðara reynist fyrir minni skipulagsheildir að innleiða gæðakerfi (Dellana og Kros, 2018). Rannsókn Boiral (2011) á innleiðingu gæðastaðla sýndi fram á að helstu hindranir reyndust vera ófullnægjandi skjalastjórn eða of mikil óreiða á skjölum par sem mikill tími og bjargir fóru í skjalavinnslu tengda stöðlum. Árangur af innleiðingu gat orðið yfirborðskenndur ef stuðningur stjórnenda var ekki fyrir hendi eða ef gildi viðkomandi gæðastaðla rímuðu ekki við stefnu skipulagsheilda. Vandamál komu iðulega upp pegar skipulagsheildir freistuðu pess að komast hratt í gegnum ferlið til að koma til móts við kröfur utanaðkomandi aðila. Boiral (2012) greindi fjölda fræðigreina um innleiðingu ISO 9000 staðlaraðanna sem sýndu m.a. fram á að innleiðing peirra hafði margvíslegan ávinning í för með sér. Nefna má aukna skilvirkni í rekstri, agaðri vinnubrögð, 
betri stjórnun og ánægju starfsfólks. Helstu hindranir við innleiðingu reyndust vera flókin skjalastýring í tengslum við gæðastaðla, yfirborðskennd innleiðing og ónægur stuðningur stjórnenda.

Jóhanna Gunnlaugsdóttir $(2010,2012)$ rannsakaði innleiðingu á ISO-staðlaröðinni hjá íslenskum skipulagsheildum. Niðurstöður Jóhönnu eru sambærilegar erlendum rannsóknum. Par kom fram að helstu ástæður pess að skipulagsheildir innleiddu gæðastaðla voru að koma til móts við kröfur viðskiptavina og bæta samkeppnisstöðu sína. Vottun var einnig leið til að koma á öguðum vinnubrögðum og ná betri yfirsýn yfir eigin starfsemi. Í báðum rannsóknum kom fram að helsti ávinningur innleiðingarinnar var að mæta kröfum viðskiptavina og stjórnvalda og að innleiðing hafði i för með sér bætta stjórnun. Pá jók innleiðing alpjóðlegra gæðastaðla trúverðugleika íslenskra fyrirtækja, sérstaklega eftir efnahagshrunið. Peir pættir sem helst purfti að lagfæra fyrir vottun var skilvirk skráning og stýring skjala auk skráningar og skilgreiningar á verklagsreglum og vinnuferlum (Jóhanna Gunnlaugsdóttir, 2010, Gunnlaugsdottir, 2012).

\subsection{Kröfur jafnlaunastaðals um skjalfestingu}

Kröfur jafnlaunastaðals um skjalfestingu gæðaskjala og skráa er í samræmi við alpjóðlegan staðal um skjalastjórn ISO ÍST 15489 par sem skjöl (e. records) eru skilgreind sem sönnunargögn um starfsemi og sem upplýsingaverðmæti (ÍST ISO 15489-1:2016, 2018). Viðmið ISO 15489 eru einnig í samræmi við lög um opinber skjalasöfn nr. 77 (2014).

Skjalastjórn nær yfir skjalfestar upplýsingar bæði á pappír og rafrænu formi (Saffady, 2016) og felur í sér viðeigandi aðgerðir til að vernda uppruna, áreiðanleika, heilleika og nothæfi skjala og mæta lagalegum kröfum um sönnunargögn (Lederman, 2012; Saffady, 2016; ÍST ISO 15489-1:2016, 2018). Kerfisbundin skjalastjórn er frumskilyrði pess að hægt sé að endurheimta, lesa úr og stýra vistunartíma, aðgangsrétti og öryggi gagna (Henttonen og Kettunen, 2011). Skjalavandi er viðvarandi í nútímastarfsumhverfi par sem starfsfólk kýs að geta unnið með hvaða upplýsingar sem er, á hvaða formi sem er og hvenær sem er. Рað getur skapað hættu hvað varðar net- og upplýsingaöryggi ef ekki eru skýrar verklagsreglur og eftirlit með pví að starfsfólk skrái og visti upplýsingar (Makinen og Henttonen, 2011; Jóhanna Gunnlaugsdóttir og Árni Jóhannsson, 2013; Jóhanna Gunnlaugsdóttir og Ragna Kemp Haraldsdóttir, 2015). Lög um persónuvernd og meðferð persónuupplýsinga nr. 90 (2018) gera auknar kröfur til skipulagsheilda um skipulega stjórn á skjölum par sem skýr og aðgengileg persónuverndarstefna parf að vera til staðar sem og vinnsluskrá sem veitir yfirsýn yfir öll pau gögn sem viðkomandi vinnustaður vinnur með og varða persónuupplýsingar, svo sem launaupplýsingar og upplýsingar um menntun og hæfni starfsfólks. Háar fjárhæðir geta verið í húfi ef ákvæðum laganna er ekki fylgt (Haraldsdottir, 2020).

Í rannsókn sem varðaði skráningu persónulegrar pekkingar starfsfólks í tengslum við innleiðingu jafnlaunastaðals bentu Haraldsdottir o.fl. (2018) á að með pví að skrá pekkingu starfsfólks skipulega og gera hana aðgengilega mætti nýta betur pá pekkingu sem býr í starfsfólkinu, byggja upp pverfagleg teymi og auka gagnsæi sérfræðipekkingar og reynslu starfsfólks á vinnustað. Pá kom fram að skráning upplýsinga um menntun og hæfni gæfi yfirsýn yfir pá pekkingu sem safnast hefur saman og gæti auðveldað starfsfólki, sér í lagi stjórnendum, að meta pekkingarstöðu og finna starfsfólk með viðeigandi menntun í sértæk verkefni.

pekking og hæfni starfsfólks er talin ein mikilvægasta auðlind skipulagsheilda og rannsóknir benda til pess að pekkingarstjórnun auki samkeppnishæfni og rekstrarárangur (Andreeva og Kianto, 2012; Zheng, 2017) sem og framsækni og aðlögunarhæfni skipulagsheilda (Sigala og Chalkiti, 2014). Fram kemur á vef SA, sem einmitt er einn brautryðjenda jafnlaunavottunar að „,[f]yrirtæki eru námsstaðir, öðruvísi en skólar, en mikilvægur páttur menntunar í landinu“" (Samtök atvinnulífsins, e.d.). Samkvæmt SA sinna mörg fyrirtæki menntahlutverkinu af miklum metnaði par sem pekking og færni starfsfólks er í sífelldri 
próun. Samtök iðnaðarins leggja einnig áherslu á menntun starfsfólks par sem pví er haldið fram að ,[m]enntakerfið rækt[i] pekkingu, leikni og hæfni einstaklinga og styð[ji] pannig við efnahagslega velmegun og lífsgæði einstaklinga“ (Sigurður Hannesson, 2019).

Skráning menntunar hefur einnig verið rannsökuð í tengslum við símenntun á vinnustöðum par sem tímar til menntunar voru mældir, flokkaðir og skráðir í samræmi við parfir einstakra starfa eða til að framfylgja utanaðkomandi reglugerðum um menntun og pjálfun starfsfólks (Becker og Gerhart, 1996; Thunnissen o.fl., 2013). Í íslenskri rannsókn á tilgangi skráningar á pekkingu starfsfólks kom fram að helsti ávinningur skráningar væri bætt ákvarðanataka og aukin framleiðni, minnkun kostnaðar og uppbygging pverfaglegra teyma (Grimsdottir og Edvardsson, 2018). Niðurstöður rannsóknar sem fjallaði um skráningu á persónulegri pekkingu starfsfólks hjá íslenskum skipulagsheildum sem unnið höfðu til pekkingarverðlauna sýndu að skipulagsheildir sem unnið höfðu til verðlaunanna höfðu ekki betri skráningu eða yfirsýn en pær sem ekki höfðu hlotið verðlaun, prátt fyrir að viðmælendur teldu skráningu pekkingar hafa fjárhagslegan ávinning í för með sér til lengri tíma. Skráningin var talin erfiðleikum háð vegna upphafskostnaðar, tímaskorts og takmarkaðs aðgangs starfsfólks og stjórnenda að skráðum upplýsingum. Pá sýndu niðurstöður að sú menntun eða pekking sem telja mætti lögbundna skyldu samkvæmt innlendum eða erlendum regluverkum var skráð en annars konar pekking reyndist ekki skráð (Haraldsdottir, 2020).

\section{Aðferðafræði}

Rannsóknin sem hér er kynnt fjallar um innleiðingu jafnlaunastaðals ÍST 85:2012 hjá íslenskum skipulagsheildum. Markmið hennar var að varpa ljósi á innleiðingarferli jafnlaunastaðals hjá skipulagsheildum sem hlotið höfðu jafnlaunavottun. Skoðað var hvaða pættir voru taldir styðja við slíkt innleiðingarferli og hverjar voru helstu hindranir. Pá var kannað hvernig staðið var að vistun gagna í samræmi við kröfur staðalsins en rík áhersla er á kerfisbundna skráningu í jafnlaunastaðli, bæði hvað varðar hefðbundin gæðaskjöl og alla skráningu fylgigagna til sönnunar ákvarðana og/eða gjörða (ÍST 85:2012, 2012). Að lokum var skoðað hvernig haldið var utan um skjalfestar upplýsingar í tengslum við launasetningu og launaákvarðanir, líkt og krafist er í jafnlaunastaðli. Leitast var við að ná pessum markmiðum með pví að nota eigindlega aðferðafræði (e. qualitative methodology) við söfnun gagna (Silverman, 2017). Eigindlegar rannsóknaraðferðir urðu fyrir valinu par sem slík nálgun veitir innsýn við að skilja rannsóknarefnið í raunverulegum aðstæðum og fanga sjónarmið, reynslu og upplifun viðmælenda (Esterberg, 2002; Taylor o.fl., 2016). Âkveðið var að nota fleiri en eina aðferð við söfnun gagna í rannsókninni. Pannig eru upplýsingar frá mismunandi auðlindum notaðar til að auðvelda rannsakanda að öðlast dýpri skilning á viðfangsefninu. Meginpungi rannsóknargagna fól í sér hálfopin djúpviðtöl (e. in-depth interviews) en auk peirra var rannsóknin byggð á fyrirliggjandi gögnum (e. secondary data). Rannsóknin var framkvæmd 2018-2019 og 2020. Fyrirliggjandi efni var kannað á pessum árum. Viðtöl fóru fram 2018-2019.

Skipulagsheildirnar sem tóku pátt í rannsókninni voru valdar kerfisbundið. Haft var samband við ýmist mannauðsstjóra eða skjalastjóra sex skipulagsheilda af lista Jafnréttisstofu yfir skipulagsheildir sem höfðu hlotið jafnlaunavottun við upphaf rannsóknar. Leitast var eftir að fá viðtal bæði hjá opinberum skipulagheildum og einkareknum. Ástæðan er sú að munur er á regluverki tengdu skjalahaldi einkarekinna skipulagsheilda og opinberra par sem opinberum stofnunum er skylt að fara að lögum um opinber skjalasöfn, nr. $77 / 2014$.

Fyrirliggjandi gögn geta verið hvers konar rituð gögn, svo sem efni frá fjölmiðlum og ýmiss konar opinber gögn, p.e. skýrslur, leiðbeiningar, tillögur, tilkynningar, fundargerðir og álit, en einnig efni sem fengið er með bréfum, dagbókarskrifum, tölvupóstum eða af vefsíðum (Esterberg, 2002). Greindar voru athugasemdir um jafnlaunastaðal í öllum erindum 437. máls á 146. löggjafarpingi: jöfn staða og jafn réttur kvenna og karla. Öll fyrir- 
liggjandi gögn voru skoðuð út frá innihaldi (e. content analysis). Pannig er rýnt í innihald og áherslur með pví að lesa gögnin gaumgæfilega og skrá helstu hugtök og orðasambönd sem tengjast viðfangsefninu, svo sem jafnlaunavottun, jafnlaunastaðall, jafnlaunaúttekt, jafnrétti og jöfn laun. Skoðuð voru atriði sem fjölluðu um væntanlegan ávinning jafnlaunavottunar sem og pau atriði sem greindu frá ókostum hennar. Auk pess var sérstaklega horft til texta sem fjallaði um skráningu eða skjalfestingu. Fyrirliggjandi gögn voru fyrst skoðuð í tengslum við undirbúning viðtalsramma og síðan í endurteknum samanburði við viðtölin með раð að markmiði að skilja betur innihald og notagildi (Charmaz, 2014; Prior, 2011). Auk erinda tengd 437. máli 146. Löggjafarpings var jafnlaunastaðallinn ÍST 85:2012 lesinn gaumgæfilega m.t.t. krafna og rýnt í fjölmiðlaumfjöllun á árunum 20182020 með раð аð markmiði að fylgja eftir umfjöllun um innleiðingu staðalsins. Fyrirliggjandi gögn geta reynst góð heimild pegar kemur að pví að átta sig á pví hvernig málum hefur verið lýst, hvernig pau hafa próast eða hvernig pau tengjast (Prior, 2011). Samanburður á mismunandi tegundum gagna sem aflað hefur verið með ólíkum aðferðum getur sýnt fram á misræmi eða samhljóm á milli pess sem kemur fram í viðtölum og/eða birtist í fyrirliggjandi gögnum (Sigríður Halldórsdóttir, 2013; Taylor o.fl., 2016).

Tekin voru tíu hálf-stöðluð (e. semi-sturctured) djúpviðtöl í sex skipulagsheildum. Eitt viðtalið (skipulagsheild $\mathrm{F}$ ) var hópviðtal með tveimur viðmælendum. Við val á viðmælendum var notað markvisst úrtak (e. purposive sampling). Pátttakendur voru valdir með раð аð markmiði að peir hefðu yfirgripsmikla reynslu og pekkingu af viðfangsefninu og gætu pannig veitt innsýn í helstu hindranir og/eða pau atriði sem auðvelda innleiðingu jafnlaunastaðals (Braun og Clarke, 2013). Viðmælendur höfðu ólík starfsheiti og báru ýmist ábyrgð á mannauðsmálum, skjalastjórn og/eða gæðastjórnun. Með pví að taka viðtal við löggiltan úttektaraðila var leitast við að fá innsýn í sjónarhorn eftirlitsaðila að innleiðingarferlinu. Með fjölbreyttu vali á viðmælendum var reynt að fá sem breiðasta mynd af stöðu jafnlaunavottunar (Braun og Clarke, 2013). Tafla 1 sýnir yfirlit yfir viðmælendur rannsóknarinnar.

Tafla 1. Viðtöl

\begin{tabular}{lllll}
\hline Skipulagsheild & Rekstrarform & Viðtalsform & Viðmælendur & Starfsheiti \\
\hline Skipulagsheild A & Opinber & Einstaklingsviðtöl & Viðmælandi 1 & Gæðastjóri \\
& & & Viðmælandi 2 & Starfsmannastjóri \\
Skipulagsheild B & Einkarekin & Einstaklingsviðtöl & Viðmælandi 3 & Gæða- og skjalastjóri \\
& & & Viðmælandi 4 & Mannauðsstjóri \\
Skipulagsheild C & Opinber & Einstaklingsviðtal & Viðmælandi 5 & Skjala- og gæðastjóri \\
Skipulagsheild D & Einkarekin & Einstaklingsviðtal & Viðmælandi 6 & Mannauðsstjóri \\
Skipulagsheild E & Opinber & Einstaklingsviðtal & Viðmælandi 7 & Mannauðsstjóri \\
Skipulagsheild F & Opinber & Hópviðtal & Viðmælandi 8 & Starfsmannastjóri \\
& & & Viðmælandi 9 & Sérfræðingur á \\
& & & & starfsmannasviði \\
Vottunarstofa & Einkarekin & Einstaklingsviðtal & Viðmælandi 10 & Úttektaraðili \\
\hline
\end{tabular}

Rannsakendur settu saman viðtalsramma en héldu sig ekki við ákveðna röð spurninga eða orðalag (Braun og Clarke, 2013). Í lok hvers viðtals fékk viðmælandi tækifæri til að bæta við pví sem viðkomandi lá á hjarta og hafði ekki verið rætt í viðtalinu (Kvale og Brinkmann, 2009). Viðtölin voru hljóðrituð og í kjölfarið afrituð með athugasemdum og hugleiðingum. Við greiningu viðtala var stuðst við aðferð grundaðrar kenningar (e. grounded theory) par sem greining var gerð samhliða gagnaöflun og sífelldur samanburður getur átt sér stað. Gögnum var safnað í peim tilgangi að gefa fjölbreytta mynd af viðfangsefninu og próa pannig kenningar og tilgátur sem byggjast á gögnunum fremur en fyrirfram gefnum hugmyndum (Charmaz, 2014; Taylor o.fl., 2016). Að lokinni afritun viðtala var farið kerfisbundið yfir gögnin. Pau voru marglesin af nákvæmni og kóðuð samhliða og eftir gagnaöflun (Taylor o.fl., 2016). Lengd viðtala var á bilinu 29-52 mínútur eða að meðaltali 38 
mínútur. Samtals voru viðtölin 295 mínútur. Öllum viðmælendum var heitið nafnleynd til að tryggja trúnað og að ekki mætti tengja pá við pær skipulagsheildir sem peir starfa hjá (Gorman og Clayton, 2005).

\section{Niðurstöður}

Við greiningu viðtala komu fram fjögur meginpemu ásamt fjölda undirpema og hafa peim verið gerð ítarleg skil (Guðbjörg Ingunn Óskarsdóttir, 2019). Við greiningu á fyrirliggjandi gögnum úr 437. pingmáli 146. löggjafarpings komu fram fimm pemu. Í pessari grein er aðeins fjallað um nokkrar helstu niðurstöður rannsóknarinnar.

\subsection{Samvinna og skipulag}

Viðmælendur töluðu flestir um að hafa innleitt jafnlaunastaðal í samstarfi við aðra. Allar skipulagsheildirnar sem tóku pátt í rannsókninni voru með mannauðsstjóra og/eða gæðastjóra sem komu að innleiðingunni. Auk pess höfðu skipulagsheildir A, B, D, E og F farið í gegnum jafnlaunaúttekt PwC eða jafnlaunavottun VR fyrir innleiðingu staðalsins. Viðmælendum bar saman um að pað að hafa farið í gegnum slíkt ferli hafi reynst vel við innleiðinguna. Viðmælandi hjá skipulagsheild E sagði: „Við vorum auðvitað betur undirbúin, af pví að við vorum búin að fara í úttektina [...] Án peirra [PwC] hefði ég kannski ekki alveg áttað mig á hvernig væri best að byrja á verkefninu." Algengast var að mannauðsstjórar og gæðastjórar ynnu saman að innleiðingunni. Sumir viðmælendur nefndu að peir væru hluti af vinnuhópi sem í sátu fleiri stjórnendur og sérfræðingar eða eins og kom fram hjá mannauðsstjóra skipulagsheildar F: „pað voru lykilstjórnendur hérna innanhúss sem að komu með okkur inn í petta og svona, já sérfróðir aðilar innanhúss sem pekktu viðkomandi störf betur en við." Auk pess nefndi viðmælandi hjá skipulagsheild F samstarf við gæðastjóra og starfsmann í launa- og kjaramálum. Mannauðsstjóri hjá skipulagsheild B talaði á svipuðum nótum og sagði: „vinnuhópurinn var aðallega ég og gæðastjóri og framkvæmdarstjórn." Hjá öllum skipulagsheildum starfaði upplýsingafræðingur sem sá um skjalastjórn. Upplýsingafræðingarnir tóku allir, að undanskildum peim sem starfaði hjá skipulagsheild E, en mismikið pátt í skjölun tengdri innleiðingarferlinu. Pátttaka upplýsingafræðinga gat skipt sköpum við innleiðinguna eða eins og mannauðsstjóri skipulagsheildar B komst að orði:

Ég pekki alveg launasetningu, ég pekki pað allt. En pað að vera að mæta kröfum svona staðals með alls konar einmitt skjölun og rekjanleika og frávikum og pessu og hinu, pú veist, pað var nýtt fyrir mér. Pannig að par var gífurlega mikilvægt að hafa góðan gæðastjóra og góðan skjalastjóra.

Viðmælendur voru sammála um að staðallinn gerði ríka kröfu um skjalfestingu og mikilvægt að skipulag gagna væri í lagi áður en innleiðing hæfist. Viðmælandi hjá skipulagsheild B sagði:

Pú færð ekki svona vottun og heldur henni nema skjalamálin séu á hreinu [...] Pú getur kannski fengið hana einu sinni en gangi pér vel að halda henni ef pú ert ekki með skjölunina í lagi [...] Pú parft að vera með skjölunina í lagi, pað er bara númer eitt, tvö og prjú.

Greina mátti á svörum viðmælenda að traustur grunnur í skráningu upplýsinga um menntun og hæfni starfsfólks væri innleiðingunni verulega til framdráttar. Eða eins og fram kom hjá viðmælanda í skipulagsheild A: „Við eigum rökstuðning fyrir öllum, nánast öllum launabreytingum frá árinu 1999. •að gaf okkur pvílíkt forskot og pýddi að við gáum farið nokkuð hratt í gegn." Pannig töluðu viðmælendur um að geta mætt kröfum jafnlaunastaðals með peim gögnum sem pegar voru til staðar. Flestir viðmælendur nefndu að 
peirra skipulagsheild væri betur í stakk búin að innleiða jafnlaunastaðal en aðrar sem pau vissu um. Í pví samhengi töluðu viðmælendur um einsleitan starfsmannahóp, formfast umhverfi, aðrar vottanir og gott skipulag gagna með par til gerðum kerfum. Viðmælandi hjá skipulagsheild D sagði:

Við áttum kerfið [...] ég hugsa sko fyrirtæki sem standa núna frammi fyrir pví að eiga kannski ekki skráð verklag eða starfslýsingar eða eru ekki með launa eða mannauðskerfi eða svona skjalakerfi. Pú veist maður hugsar bara, pað verður erfitt.

Viðmælendur í opinbera geiranum nefndu að auðveldara væri fyrir opinberar aðila að innleiða staðalinn par sem peir byggju við formfastara umhverfi en mörg einkafyrirtæki. Viðmælandi hjá skipulagsheild C sagði:

Petta var mun einfaldara og minni vinna fyrir okkur en marga aðra [...] maður sér suma bara reita hár sitt og finnast petta óyfirstíganlegt verkefni og рað getur verið рað [...] fyrir einkafyrirtæki sem er ekki með neina skilaskyldu og purfa par af leiðandi ekki að vera með neina skjalastjórn.

Skipulagsheildir A, B, D og F voru allar með gæðakerfi áður en innleiðing jafnlaunastaðals hófst. Greina mátti á svörum viðmælenda að heilmikill ávinningur fólst í pví. Viðmælandi hjá skipulagsheild A sagði: „Pegar við fórum í verkefnið áttuðum við okkur á að pað er byggt upp á nákvæmlega sama hátt og gæðakerfið. Раð eru pessar grunnverklagsreglur sem eru í báðum stöðlum. “ Viðmælandi hjá skipulagsheild D tók í sama streng:

Við áttum náttúrulega allt gæðakerfið og stjórnkerfið. Við purftum bara að skoða hvort við uppfylltum allar kröfurnar, eru einhverjar aðrar kröfur eða nýjar kröfur miðað við staðlana sem við erum með? Einstaka sinnum purftum við að setja inn línu um jafnlaunavottunina en pað voru engar verklagsreglur gæðamegin sem við purftum að búa til upp á nýtt. En við purftum náttúrulega að gera verklagsreglur um ákvörðun launa og uppbyggingu launakerfis og launaviðmið.

Pannig nefndu viðmælendur að peir gætu samnýtt gæðaskjölin milli ólíkra gæðastaðla sem fyrir voru og lagað að kröfum jafnlaunastaðals. Svör viðmælenda voru í samræmi við reynslu úttektaraðila sem sagði:

Раð er svolítil vinna að skrifa verklagsreglurnar í kringum stjórnkerfið fyrir pau sem eru ekki með vottun fyrir [...] en mörg fyrirtæki eru með einhvern vísi af starfslýsingum sem pau geta pá notað sem grunn [...] petta er allt orðið í kerfum, bókhaldskerfum pannig að allar skrár varðandi laun og svoleiðis eru par.

\section{2 Álag og ávinningur}

Viðmælendum bar saman um að innleiðingarferli jafnlaunastaðals væri tímafrekt og tímaskort bar oft á góma pegar spurt var út í erfiðleika eða hindranir við innleiðinguna. Hjá mörgum kom fram að par sem fáir faggiltir vottunaraðilar væru í landinu væri mikilvægt að panta tíma í úttekt með góðum fyrirvara. Viðmælandi hjá skipulagsheild A greindi frá langri bið eftir tíma í úttektina sem tafði fyrir innleiðingarferlinu: „Við vorum löngu tilbúin en peir bara komu ekki og komu ekki sko. Pess vegna hérna fengum við tilboð bæði frá Vottun og BSI en peir voru bara rosalega uppteknir [...] pað tók lengstan tíma hjá okkur." Margir viðmælendur voru sammála um að best væri að gera ráð fyrir rúmum tíma í inn- 
leiðingarferlið pví ekki væri hægt að „redda“ pví með skömmum fyrirvara. Mikill tími fór í starfaflokkun, að átta sig á jafnlaunakerfinu og finna til allar upplýsingar sem purfti til að standast kröfur staðalsins. Pannig gat farið mikill tími í að máta kerfið sem var til staðar og aðlaga pað eða útbúa nýtt kerfi sem hentaði fyrir jafnlaunavottun. Viðmælandi hjá skipulagsheild F sagði:

Petta eiginlega tók meiri tíma heldur en við héldum og hérna við vorum líka mjög fegin bara að hafa ekki tímapressu líka á sér af pví að pað var hangandi parna áramóta deadline og við vildum alls ekki lenda í einhverju skralli með рað í nóvember og desember pannig að pað var mjög fínt að vera búin að hafa tíma til að fara vel yfir starfaflokkun og prófa sig aðeins áfram með tölfræði og annað í næði. Рað var bara mjög mikilvægt.

Einnig kom í ljós að vinnan við innleiðinguna bættist við hefðbundin störf eða eins og viðmælandi hjá skipulagsheild A komst að orði:

Petta er tímafrekt. Pað tekur tíma að búa til kerfi sem virkar og er rekjanlegt. Petta tók hellings tíma [...] En við purftum að vinna annað með en sko ... petta er tímafrekt pegar maður er að koma kerfinu í gegn. Pess vegna sögðum við [mannauðsstjóri] á einhverjum tímapunkti, bíddu, á starfsemi [stofnunarinnar] að snúast um pað að vera í jafnlaunavottun?

Pegar úttektaraðili var spurður út í tímapáttinn og frestinn sem gefinn hafði verið á innleiðingunni sagðist hann telja að hluti vandans gæti verið sá að „menn eru að fara alltof seint af stað [...] Við finnum pað núna, pað voru mörg fyrirtæki sem vildu klára sig fyrir áramót núna svo kom fresturinn pá svona humm ... minnkar aftur".

Viðmælendur voru sammála um að starfaflokkun væri oft hindrun við innleiðinguna, bæði flækti hún fyrir og tók mikinn tíma. Pá kom fram að ÍSTARF-númerin væru orðin gömul og úrelt. Viðmælandi hjá skipulagsheild F sagði:

Við kannski gerðum okkur í hugalund að pað [ÍSTARF-flokkun] yrði til grundvallar áður en við byrjuðum en svo var pað bara að einhverju leyti úreltar flokkanir og pössuðu ekki vel við og svona. Раð var bara ljóst að раð purfti að gera petta alveg frá grunni ef við ætluðum að fylgja pessari aðferðafræði og við bara gerðum pað.

Hjá skipulagsheild D kom fram að pau hefðu í raun purft að taka upp hálfúrelt verklag par sem pau væru með hlutverkalýsingar inni í kerfinu hjá sér en starfslýsingar hefðu verið víkjandi. Nokkrir viðmælendur töluðu um að hafa purft að endurnýja kerfin samhliða jafnlaunavottun. Viðmælandi hjá skipulagsheild E sagði:

Við purftum að byrja á pví að gera alls konar uppfærslur á kerfi, setja inn ákveðin grunngögn sem voru bara ekki til staðar [...] Рað tók rosalegan tíma [...] Svo kom í ljós að pað hefði verið gott að hafa mannauðskerfi svo menntun og annað kæmi inn. Pá bættum við inn mannauðskerfinu.

Mörgum viðmælendum fannst staðallinn of punglamalegur og umfangsmikill. Viðmælandi hjá skipulagsheild F sagði: „Pannig að petta er fínt tæki en petta er í sjálfu sér júmbópota í staðinn fyrir flugdreka sko pú veist. Petta er óparflega mikið kerfi miðað við pann tilgang sem er að baki.“ Að mati flestra viðmælenda væri æskilegt að reyna að einfalda jafnlaunakerfið par sem tilgangur kerfisins væri að hjálpa skipulagsheildum en ekki gera peim erfiðara fyrir. Viðmælandi hjá skipulagsheild D komst svo að orði: 
Mín skilaboð eru bara, ekki ofhugsa petta, byrjið bara í basic-inu og skoðið hvað pið hafið. Og mátið fyrst áður en pið farið í Excel-skjalið og gjörsamlega missið fótanna. Ekki pað аð pað sé ekki gott og gilt en pað er mjög flókið [...] hlustið ekki á petta málfar í staðlinum, petta er miklu einfaldara en staðallinn segir til um.

Viðmælandi hjá skipulagsheild C talaði á sömu nótum: „En svo hef ég líka alveg séð hann sko petta kerfi [jafnlaunastaðal] sett upp miklu flóknara, miklu stærra og fleiri skjöl. Ég held að fólk hafi bara aðeins verið að flækja málin." Viðmælandi af úttektarstofu tók í sama streng:

Ég held að menn ofmeti vinnuna við petta, petta er miklu minni vinna en menn halda. Öll fyrirtæki eru að greiða laun [...] pau vita alveg hvað pau eru að borga mönnum mikil laun. Fyrir flest fyrirtæki er petta bara pörun.

Úttektaraðilinn taldi að jafnlaunavottun gæti orðið mun einfaldari í framtíðinni, einhvers konar rafræn stýring, jafnvel próast inn í bókhaldskerfi fyrirtækja og verið partur af starfseminni, eins og skil til skattsins. Hann tók pó fram að alltaf purfi að kerfisbinda ákvarðanir um laun og hafa utanaðkomandi eftirlit sem sannreyni að fólk geri pað sem pað segist gera.

Allir viðmælendur nefndu að mikill ávinningur hlytist af jafnlaunavottun. Með vottuninni gætu skipulagsheildir sýnt fram á jafnrétti og réttlæti í launasetningu. Með innleiðingu staðalsins kæmust á agaðri vinnubrögð, aukin kerfisbinding og gagnsæi ákvarðana. Viðmælandi hjá skipulagsheild B nefndi að par hefði ánægja með jafnréttismál aukist eftir jafnlaunavottun: „Starfsmennirnir okkar treysta pví að petta sé gegnsætt og réttlátt. Peir eru mjög ánægðir með petta og stoltir af vottuninni eins og við stjórnendur. Stolt af pví аð pað mældist lítill munur." Viðmælendur hjá skipulagsheildum B og D nefndu að peim fyndist mikilvægt að hafa utanaðkomandi aðila sem votti að skipulagheildirnar séu að borga sambærileg laun fyrir sambærileg störf óháð kyni. Viðmælandi hjá skipulagsheild D sagði í pessu sambandi:

Раð er kannski hægt að skrifa sig frá pessu en parna parf fólk að hugsa sig aðeins um áður en pað setur laun á einstaklinga. Раð er einhver sem er að fylgjast með. Ég held að allir vandi sig betur.

Viðmælandi hjá skipulagsheild A tók undir og sagði: „,[rökstuðningur] kemur í veg fyrir að forstjóri geti bara sagt já, já pú ert svo frábær starfsmaður pú færð bara launahækkun.“ Annar viðmælandi á sama stað var á sama máli og taldi mikilvægt að allar launaákvarðanir væru málefnalegar og rökstuddar. Viðmælandi hjá skipulagsheild B var sammála og taldi mikilvægt að allar launaákvarðanir væru miðlægar og færu í gegnum mannauðsteymið. Hann tók fram að jafnlaunastaðall veitti ákveðið aðhald af pví að „pað getur ekki einhver framkvæmdarstjóri eða forstöðumaður bara allt í einu hækkað einhver laun af pví bara". Viðmælandi rannsóknarinnar sem starfar sem úttektaraðili tók undir pessi sjónarmið og sagði pað hjálpa skipulagsheildum að vera með skýr viðmið pannig að allir viti að hverju peir ganga. Hann sagði:

Ef pau eru ekki skýr pá er, hvað á ég að miða við, Gunna er svo frábær, en hvað er pað nóg? pú veist, eða er pað bara freki karlinn sem ræður alltaf og раð hefur svolítið verið pannig að freki karlinn hefur ráðið og fengið launahækkanirnar. Nú ætti pað vonandi að hætta. 
Úttektaraðilinn tók pó fram að jafnlaunastaðall leysti ekki allan vanda. Hann benti á launamunur leyndist helst í heildarlaunum pví að konur vinni síður yfirvinnu en karlar og fái par af leiðandi lægri heildarlaun. Hann benti jafnframt á að pað að vinna yfirvinnu eftir klukkan fimm sé menningarlegt fyrirbæri og að pau fyrirtæki sem hafi boðið upp á yfirvinnu fyrir klukkan átta á morgnana hafi reynslu af pví að fleiri konur taki að sér yfirvinnu á peim tíma. Hann hélt pví fram að með pví að skoða hlutina kerfisbundið, eins og með tilkomu jafnlaunastaðals, væri hægt að sjá pá í öðru ljósi pví sumt sé einfaldlega í viðjum vanans. Margir viðmælendur töluðu um mikilvægi pess að njóta stuðnings stjórnenda eða eins og viðmælandi hjá skipulagsheild $\mathrm{A}$ komst að orði: „Forstjórinn verður náttúrulega alltaf að hafa framgang um petta allt, svona gengur ekki nema forstjórinn sé klappstýra númer eitt, tvö og prjú."

\subsection{Lögfesting jafnlaunavottunar}

Páttur í rannsókninni var greining á fyrirliggjandi gögnum með áherslu á innsend erindi og umsagnir um 437. mál: jöfn staða og jafn réttur kvenna og karla (jafnlaunavottun) frá 146. Löggjafarpingi. Við greiningu gagna kom fram að staðallinn gæti veitt falskt öryggi í tengslum við launajafnrétti kynjanna, kostnaður við innleiðingu gæti orðið ípyngjandi, tímabært væri að endurmeta staðalinn og að eftirliti væri ábótavant. Umsagnaraðilar sáu einnig ávinning af innleiðingu jafnlaunastaðals. Mynd 1 sýnir helstu niðurstöður greiningarinnar:

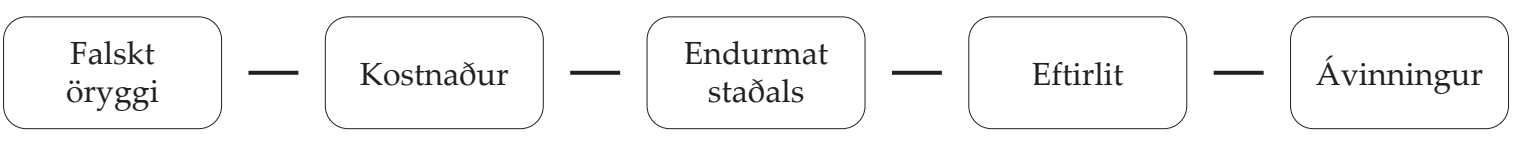

Mynd 1. Niðurstöður greiningar á 437. pingmáli á 146. löggjafarpingi

Fram kom að jafnlaunastaðallinn gæti veitt falskt öryggi í tengslum við launajafnrétti kynjanna par sem staðallinn tæki til að mynda ekki á launamismunun gagnvart starfsstéttum par sem atvinnugrein og starfstétt skýra stærstan hluta launamunar konum í óhag.

Kostnaður við innleiðingu gæti orðið ípyngjandi fyrir mörg fyrirtæki, sér í lagi pau smærri sem hafa ekki sérstakan mannauðsstjóra eða sérfræðinga í stöðlum. Fjöldi skipulagsheilda pyrfti að kaupa hugbúnað til að halda utan um og stýra skrám sem staðallinn gerir kröfu um. SA lagði áherslu á að aldrei hafi verið markmiðið við gerð staðalsins að hann yrði lögfestur. Sama hafi átt við um jafnlaunastaðal og aðra stjórnunarstaðla, svo sem ISO 9001 gæðastjórnunarkerfi og IS0 14001 umhverfisstjórnunarkerfi, að honum var ætlað að vera valkvæður.

SA hélt pví fram að endurskoða pyrfti staðalinn og kröfur sem gerðar eru til skipulagsheilda. Mælt var með að tíminn fyrir innleiðingu yrði rýmkaður svo hægt væri að meta árangur vottunar og fá betri reynslu á innleiðingarferlið. Hagstofa Íslands benti á að jafnlaunastaðallinn gerði kröfu um að flokka og skilgreina störf kerfisbundið. Reynslan hafi sýnt að kerfið ÍSTARF95 væri úrelt flokkunarkerfi. Nauðsynlegt væri að innleiða nýja starfaflokkun áður en jafnlaunavottun yrði lögfest svo hægt væri að endurspegla vinnumarkaðinn eins og hann liti út nú. Einnig var bent á að mælanleg markmið skorti og að bjóða pyrfti upp á betri hjálpargögn til að auðvelda innleiðingu staðalsins, t.d. forvinnu fjölda gæðaskjala og sniðmáta til að flýta fyrir og auðvelda vottunarferlið.

Eftirliti var talið ábótavant, styrkja pyrfti stöðu Jafnréttisstofu, sem skorti bæði fé og mannafla til að sinna lögbundnu hlutverki sínu. Eins kom fram að ákveðið ófremdarástand ríkti í faggildingarmálum hér á landi en ítrekað hefur komið fram í fjölmiðlum að takmarkaður fjöldi úttektaraðila, sem í upphafi voru aðeins tveir, sé flöskuháls í kerfinu.

Margir umsagnaraðilar töldu pó ávinning af lögfestingu jafnlaunavottunar. Jafnréttisstofa lagði t.a.m. áherslu á að Íslendingar hefðu staðið sig betur en flestar pjóðir í glímunni við kynjamisrétti. Pað sýndi kjark að koma með nýjungar og vera í fararbroddi pótt fram- 
kvæmdin kynni að reyna á. Gagnsætt og sanngjarnt launakerfi fengist sem og aukin meðvitund stjórnenda á mismunun sem falist getur í launasetningu.

\section{Umræða og samantekt}

Pótt ekki sé hægt að alhæfa um niðurstöðurnar gefa pær mikilvægar vísbendingar. Skjalfesting jafnlaunakerfis er veigamikill páttur í innleiðingu jafnlaunavottunar. Kröfur jafnlaunastaðals um skjalfestingu eru skýrar og nauðsynlegar til að uppfylla skilyrði gæðavottunar (ÍST 85:2012, 2012; Helgi Pór Ingason, 2015). Skjalfestingin er á hinn bóginn talin ípyngjandi og jafnvel óparfa skriffinnska eða kerfisvæðing sem vinni gegn markmiðum jafnlaunavottunar um að draga úr kynbundnum launamun (Helgi Tómasson, 2017; Halldór Benjamín Porbergsson, 2017; Gerða Björg Hafsteinsdóttir o.fl., 2020). Skjalfesting er pó órjúfanlegur páttur gæðastjórnunar, hvort sem um er að ræða alpjóðlega gæðastaðla líkt og ISO 9000, ISO 27000 og ISO 14000 eða séríslenskan staðal eins og jafnlaunastaðal. Gæðaskjölin skapa ramma um gæðakerfið og skrárnar eru til sönnunar um að farið hafi verið eftir ákvörðunum sem teknar hafa verið (Jóhanna Gunnlaugsdóttir, 2003; Gunnlaugsdottir, 2012). Gagnsæi jafnlaunakerfisins, rekjanleiki mála og skilyrðislaus ábyrgð stjórnenda er skjalfest, sem eykur traust starfsfólks (Wagner, 2018, 2020; Stjórnarrád Islands, 2021b).

Staðlar verða ekki til í tómarúmi. Hagsmunaaðilar koma sér saman um hvað sé hæfilegt og eðlilegt um góðar starfsvenjur og gæta pess að viðkomandi staðall sé í takt við tímann. Við gerð gæðastaðla er leitast við að lýsa pví „,hvaða kröfur eru gerðar og leiðbeint um pað hvernig má uppfylla pær, fremur en að peir lýsi ákveðnu ferli eða fyrirfram mótuðum aðferðum“ (Staðlaráð Islands, 2020, bls. 4). Pannig hafa skipulagsheildir ákveðið frelsi til að ákveða hvernig skuli fylgja stöðlum svo lengi sem pær uppfylli kröfur peirra og úttektir faggildra vottunaraðila (Helgi Pór Ingason, 2015). Kröfur jafnlaunastaðals um skjalfestingu samræmast ákvæðum laga um opinber skjalasöfn, nr. 77/2014, og lögum um persónuvernd og vinnslu persónuupplýsinga, nr. 90/2018. Pví er mikilvægt að̃ stjórnendur geri ráðstafanir til að stuðla að skilvirkri skjalastjórn til að styðja við gæðastarf og öfugt. Innlendar og erlendar rannsóknir benda til pess að krafan um skjalfestingu sé ein erfiðasta hindrunin sem skipulagsheildir standa frammi fyrir pegar kemur að gæðavottun (Bell og Omachonu, 2011; Jóhanna Gunnlaugsdóttir, 2003, 2010; Lemieux, 1996; Gerða Björg Hafsteinsdóttir o.fl. 2020).

Раð hversu erfiðlega virðist ganga að fylgja kröfum staðalsins um skjalfestingu vekur upp spurningar um hvort innleiðing gæðastaðals, sem verkfæris til að jafna laun kynjanna, sé rétta leiðin. Skipulagsheildir sem tóku pátt í rannsókninni höfðu allar skjalastjóra og/eða gæðastjóra. Pær höfðu einnig góðar bjargir hvað varðar upplýsingakerfi, t.d. mannauðsog gæðakerfi. Petta er í takt við niðurstöður Boiral (2011) um mikilvægi pess hafa gæðakerfi eins einfalt og kostur er og samnýta vinnubrögð með öðrum stöðlum til að kerfið styddi við innleiðingu gæðastaðals. Viðmælendur lögðu áherslu á að öll gögn yrðu að vera til staðar áður innleiðingarferli jafnlaunavottunar hæfist, ekki síst par sem launaákvarðanir pyrftu að byggjast á málefnalegum rökstuðningi, starfslýsingum, upplýsingum um formlega menntun og viðbótarmenntun, sérhæfingu, fyrri starfsreynslu og aðra persónubundna pætti sem gætu haft áhrif á launasetningu. Prátt fyrir að allar bjargir og gögn væru til staðar, starfsumhverfið formfast og haldgóð reynsla af alpjóðlegum gæðastöðlum, auk gullmerkis PwC eða vottun VR, reyndist innleiðingarferlið viðmælendum erfitt og tímafrekt. Kerfið væri punglamalegt og óparflega flókið. Pannig tæki tíma að færa inn eða uppfæra grunngögn og fólk væri pegar störfum hlaðið. Sumar skipulagsheildir færu of seint af stað og næðu ekki vottun á tilskildum tíma.

Gagnrýnisraddir sem getið er um í rannsókninni eru í samræmi við innsendar umsagnir hagsmunaaðila við lögfestingu staðalsins, sem bárust um 437. pingmál 146. löggjafarpings. Síðan pá hefur jafnréttislögum verið breytt. Lög um jafna stöðu og jafnan rétt kynjanna, nr. 150/2020, tóku nýlega við af fyrri lögum með peirri breytingu að minnstu skipulags- 
heildirnar sem staðallinn nær til geta nú orðið sér úti um jafnlaunastaðfestingu í stað jafnlaunavottunar. Fram kemur í athugasemdum við 8. gr. frumvarps til laga um jafna stöðu og jafnan rétt kynjanna að innleiðingu jafnlaunastaðals fylgi nokkuð umfangsmikil innleiðing á gæðastjórnunarkerfi með tilheyrandi gæðaskjölum og skrám og stýringu á gögnum sem notuð eru til grundvallar jafnlaunavottun (pskj. 14, 14. mál, 151. löggjafarping 2020-2021). Ekki er komin reynsla á 8. gr. nýrra laga um jafnlaunastaðfestingu en ferlið til að öðlast staðfestingu felur í sér nokkuð viðamikla skjalfestingu sambærilegra gagna og krafist er við jafnlaunavottun. Minnstu skipulagsheildirnar purfa áfram að setja sér stefnu í jafnlaunamálum, útbúa jafnréttisáætlun og ráđast í starfaflokkun og launagreiningu. Vinna parf áætlun um úrbætur og skila Jafnréttisstofu árlega samantekt um niðurstöður pessara gagna (Lög um jafna stöðu og jafnan rétt kynjanna nr. 150, 2020). Meginmunurinn virðist liggja í pví að pegar um jafnlaunastaðfestingu er að ræða er engin úttekt eftirlitsaðila annarra en Jafnréttisstofu. Faggildar vottunarstofur krefja pá ekki skipulagsheildir um gæðaskjöl eða aðrar skrár, eins og við vottun annarra gæðastaðla, máli sínu til sönnunar. Einnig kom fram í athugasemdum við 8. gr. nýrra laga að fjármagna pyrfti Jafnréttisstofu og tryggja nauðsynlegan mannauð og sérpekkingu til að stofnunin geti tekið að sér eins viðamikið hlutverk og eftirlit með jafnlaunastaðfestingu (sjá t.d. Katrín Björg Ríkharðsdóttir og Jón Fannar Kolbeinsson, 2020). Leiða má að pví líkum að nýtt fyrirkomulag jafnlaunastaðfestingar verði seint samanburðarhæft við vottun faggildra úttektaraðila sem hlotið hafa sampykki fyrir eigin starfsemi hjá Hugverkastofu að undanskildum skilyrðum og lögum um faggildingu o.fl. nr. 24 (2006).

Gagnrýnisraddir hafa einnig beinst að eftirlitsaðilum (Arnhildur Hálfdánardóttir, 2015) og takmörkuðum fjölda vottununaraðila sem skapaði flöskuháls í kerfinu (Ragnhildur Prastardóttir, 2019; Birna Dröfn Jónasdóttir o.fl., 2019). Рað vekur upp spurningar um pað hvort aukið eftirlitshlutverk Jafnréttisstofu á jafnlaunastaðfestingu minnstu skipulagsheildanna verði nýr flöskuháls í ferlinu, en gert er ráð fyrir að um 500 fyrirtæki og stofnanir geti nýtt sér jafnlaunastaðfestingu í stað jafnlaunavottunar. Loks kom fram sú gagnrýni að jafnlaunastaðall gæti reynst ákveðin tálsýn, eða falskt öryggi, par sem aðilar hefðu frjálsar hendur varðandi útfærslur viðmiða og gætu hagrætt niðurstöðum ef vilji væri fyrir hendi (Gerða Björg Hafsteinsdóttir o.fl., 2020). Okkar niðurstöður benda til pess að viðmælendur teldu mikilvægt að utanaðkomandi aðili vottaði jafnlaunakerfið og fylgdist með að hlutirnir væru rétt gerðir sem er í samræmi við kenningar Helga Pórs Ingasonar (2015). Með eftirliti yrðu launaákvarðanir málefnalegri, pað veitti stjórnendum aðhald og drægi úr áhrifum „freka karlsins“ sem vonandi yrði brátt úrelt fyrirbæri. Viðmælendur lögðu einnig áherslu á að jafnlaunavottun yrði ekki „reddað“ rétt fyrir tilskilinn frest. Verkefninu pyrfti að gefa góðan tíma, láta reyna á gæðakerfið og undirbúa vel fyrstu vottun sem samræmist rannsóknum Boiral $(2011,2012)$ og Kakouris og Sfakianaki (2019). Hvað varðar tálsýnina pá virtust viðmælendur treysta pví að stjórnendur vildu ná árangri með jafnlaunavottun. Markmiðið væri að koma vel út í launagreiningu til pess að sýna fram á jafnrétti í launasetningu, bæta stjórnun og vinnubrögð, auka starfsánægju og jákvætt orðspor skipulagsheildarinnar sem er í samræmi við niðurstöður Jóhönnu Gunnlaugsdóttur (2010) á 48 íslenskum fyrirtækjum með alpjóðlega vottun. Pótt hægt væri að „skrifa sig frá pessu“ par sem aðilar hefðu frjálsar hendur varðandi útfærslur viðmiða væri pað ekki markmið vottunarinnar. Hins vegar kom fram að jafnlaunavottun leysti ekki allan vanda pegar kemur að launamun kynjanna. Að hluta væri hann menningarlegt fyrirbæri sem fælist í yfirvinnu sem væri mestmegnis unnin af körlum, sem samræmist niðurstöðum Ólafar Júlíusdóttur o.fl. (2018) sem og niðurstöðum launagreiningar Hagstofu Íslands (2018).

Pá getur árangur jafnlaunavottunar orðið yfirborðskenndur ef stuðningur stjórnenda er ekki fyrir hendi eða ef hvatar viðkomandi gæðastaðla ríma ekki við stefnu skipulagsheilda (Lin og Jang, 2008; Kakouris og Sfakianaki, 2019). Fram kom hjá tilraunahópi jafnlaunavottunar að enginn stjórnandi vildi mismuna starfsfólki í launum en mismunum 
gæti pó átt sér stað. Рað væri hluti af „ómeðvitaðri kynjahlutdrægni“ (Chalaby, 2017). Petta samrýmist niðurstöðum rannsóknarinnar sem sýndi fram á að stjórnendur pyrftu að vera eins konar klappstýrur innleiðingarinnar, bæði hvað varðar innleiðingu gæðakerfa (Boiral, 2011; Jóhanna Gunnlaugsdóttir, 2010) og í tengslum við stefnu skipulagsheilda í jafnréttismálum (Boiral, 2012). Mikilvægt væri að peir hvatar sem liggja að baki innleiðingu gæðastaðla væru drifnir áfram af hugsanlegum ávinningi vottunar sem samkvæmt Staðlaráði Íslands (2020) eru aðgengi að nýjum mörkuðum, trygging fyrir gæðum, skilvirkari áhættustjórnun og hlíting laga og reglna. Ávinningur gæðavottunar var íslenskum skipulagsheildum sérstaklega mikilvægur í kjölfar efnahagshruns par sem keppikeflið var að bæta trúverðugleika íslensks viðskiptalífs (Gunnlaugsdottir, 2012). Staðlar veita pannig skipulagsheildum tækifæri til að fylgja alpjóðlega viðurkenndum venjum, auka eigin samkeppnishæfni og tryggja sanngjörn viðskipti.

Niðurstöður pessarar rannsóknar sýna að prátt fyrir gagnrýni voru viðmælendur sammála um að ávinningur jafnlaunavottunar vægi pyngra en hindranir tengdar skjalfestingu staðalsins. Með innleiðingu jafnlaunastaðals komust á agaðri vinnubrögð og skýr viðmið við launasetningu, aukið gagnsæi ákvarðana og aðgengilegri upplýsingar fyrir starfsfólk sem og stjórnendur. Rökstuðningur fyrir launaákvörðunum varð málefnalegri sem jók traust starfsfólks og starfsánægju. Pá reyndist innleiðing jafnlaunastaðals auka almennt aðhald til samræmis við umbótakröfur peirra gæðaviðmiða sem fylgja jafnlaunastaðli sem hefði áhrif langt út fyrir málaflokk jafnréttis á vinnustað (Unnur Ýr Kristjánsdóttir, 2017; Haraldsdottir og Gunnlaugsdottir, 2018; Birna Dröfn Jónasdóttir, 2019). Niðurstöður benda til pess að pær skipulagsheildir sem tóku pátt í rannsókninni hefðu haldið kerfisbundið um alla skráningu gæðaskjala og skráa, sem og grunngagna í tengslum við mannauð en með innleiðingu jafnlaunastaðals var skráningin tekin enn fastari tökum. Pannig má færa rök fyrir pví að innleiðing jafnlaunastaðals hafi stutt við skjalfestingu almennt en ekki síst peirrar pekkingar sem felst í menntun og hæfni starfsfólks sem er í samræmi við niðurstöður nýlegra rannsókna (Haraldsdottir, 2020). Niðurstöður pessarar rannsóknar koma einnig heim og saman við kannanir ráðuneyta á innleiðingu jafnlaunastaðals (Velferðarráðuneytið, 2018; Stjórnarráð Íslands, 2019; Stjórnarráð Íslands, 2021b).

Vandi peirra skipulagsheilda sem tóku pátt í rannsókninni hvað varðar tímaskort og vinnuálag, prátt fyrir góðar bjargir, er áhyggjuefni. Sá vandi, auk kostnaðar og almenns skorts á hjálpargögnum til að auðvelda innleiðingu staðalsins, hefur ekki verið leystur, prátt fyrir ný lög um jafnan rétt og jafna stöðu kynjanna, nr. 150/2020. Pá parf að bregðast við peirri gagnrýni sem snýr að takmörkuðum fjölda og ósamræmi í úttektum vottunaraðila sem sinna jafnlaunavottun, sem og skorti eftirlitsaðila á mannafla og fé til að sinna lögbundnu hlutverki sínu. Ein leiðin til að einfalda innleiðingarferlið og framkvæmd jafnlaunavottunar væri að fyrirtæki og stofnanir gætu farið í gegnum vottun á priggja ára fresti og látið af árlegum viðhaldsvottunum, pó launagreining fari fram árlega. Tafir á vottunarferlinu tengjast ofangreindum páttum. Auk pess má greina áhyggjur af pví að jafnlaunastaðallinn taki aðeins á hluta pess vanda sem skapar launamun kynjanna (Wagner, 2020; Einarsdóttir, 2020, Porvaldur S. Helgason, 2021). Hann taki til að mynda ekki á peim launamun sem tengist hefðbundnum kvenna- og karlastörfum (Guðbjörg I. Óskarsdóttir, 2019). Pvert á móti geti jafnlaunastaðallinn gefið kynbundnum launamun visst lögmæti. Vonast er til að sambærilegar rannsóknir sem nú pegar eru í farvatninu veiti innsýn í pessa mikilvægu pætti jafnlaunavottunar.

Takmarkanir pessarar rannsóknar felast helst í pví að einungis var rætt við viðmælendur hjá sex skipulagsheildum og einn úttektaraðila. Skipulagsheildirnar reyndust einnig einsleitar hvað varðar fyrri reynslu af gæðastöðlum og öðrum forverum jafnlaunavottunar. Samt sem áður er mikilvægt að fá fram reynslu peirra aðila sem hafa hvað bestar bjargir til að takast á við innleiðingu jafnlaunastaðals, ekki síður en hinna sem eiga hvað erfiðast með innleiðingarferlið. Pess er vænst að niðurstöður pessarar rannsóknar stuðli að aukinni pekkingu á innleiðingu jafnlaunavottunar og geti verið grunnur að framtíðar- 
rannsóknum. Eins gæti rannsóknin hvatt hlutaðeigandi til umhugsunar um mögulegar úrbætur fyrir vottanir næstu missera. Full ástæða er til að ígrunda frekari rannsóknir á forsendum launasetningar m.t.t. svokallaðra kvenna- og karlastarfa og mismununar sem enn ríkir í launamálum kynjanna.

\section{Heimildir}

Al-Rawahi, A. M. S. og Bashir, H. A. (2011). On the implementation of ISO 9001:2000: a comparative investigation. The TQM Journal, 23(6), 673-687. https://doi.org/10.1108/17542731111175275

Annadís Rúdólfsdóttir og Ásta Jóhannsdóttir. (2018). Fuck patriarchy! An analysis of digital mainstream media discussion of the \#freethenipple activities in Iceland in March 2015. Feminism \& Psychology, 28(1), 133151. https://doi.org/10.1177/0959353517715876

Andreeva, T. og Kianto, A. (2012). Does knowledge management really matter? Linking knowledge management practices, competitiveness and economic performance. Journal of Knowledge Management, 16(4), 617636. https://doi.org/10.1108/13673271211246185

Arnhildur Hálfdánardóttir. (2015). Jafnréttisstofa sögð máttlaus og tannlaus. RÚV. https://www.ruv.is/frett/ jafnrettisstofa-sogd-mattlaus-og-tannlaus

Ásta Dís Óladóttir, Gylfi Dalmann Aðalsteinsson og Póra Christiansen. (2019). Er skortur á framboði eða er engin eftirspurn eftir konum í æðstu stjórnunarstöður? Stjórnmál og Stjórnsýsla, 15(2), 205-228. https://doi. org/10.13177/irpa.a.2019.15.2.4

Becker, B. og Gerhart, B. (1996). The impact of human resource management on organizational performance: progress and prospects. Academy of Management Journal, 39(4), 779-801.

Bell, M. og Omachonu, V. (2011). Quality system implementation process for business success. International Journal of Quality E Reliability Management, 28(7), 723-734. https://doi.org/10.1108/02656711111150814

Benediktsdottir, S., Danielsson, J. og Zoega, G. (2011). Lessons from a collapse of a financial system. Economic Policy, 26(66), 183-235. https://doi.org/10.1111/j.1468-0327.2011.00260.x

Bhuiyan, N. og Alam, N. (2005). A case study of a quality system implementation in a small manufacturing firm. International journal of productivity and performance managment, 54(3), 172-186. https:/doi. org/10.1108/17410400510584893

Bindel, J. (2010). Iceland the world's most feminist country. The Guardian. https://www.theguardian.com/lifeandstyle/2010/mar/25/iceland-most-feminist-country.

Birna Dröfn Jónasdóttir og Sighvatur Arnmundsson. (2019, 25. júní). Aðeins priðjungur fyrirtækja hefur hlotið jafnlaunavottun. Vísir. https://www.visir.is/g/20191619534d

Boiral, O. (2011). Managing with ISO systems: Lessons from practice. Long range planning, 44, 197-220. https:// doi.org/10.1016/j.lrp.2010.12.003

Boiral, O. (2012). ISO 9000 and Organizational Effectiveness: A Systematic Review. Quality Management Journal, 19(3), 16-37. https://www.proquest.com/docview/1028004178/fulltextPDF/F5F25CFB0B6E448DPQ/1?accountid=196157

Braun, V. og Clarke, V. (2013). Successful qualitative research: A practical guide for beginners. London: Sage.

Brumm, E. K. (1996). The marriage of quality standards and records management. Records Management Quarterly, 2(30), 3-11. https://www.proquest.com/docview/227755461/fulltextPDF/6DEB1637C3C64FB2PQ/1?accountid=196157

Burri, S. (2019). European network of legal experts in gender equality and non-discrimination, National cases and good practices on equal pay. European Commission. https://doi.org/10.2838/93401

Chalaby, O. (2017). Iceland passes world's first law forcing companies to pay equally or face fines. Apolitical. https:/apolitical.co/solution_article/iceland-passes-worlds-first-law-forcing-companies-pay-equally-facefines.

Charmaz, K. (2014). Constructing grounded theory (2. útg.). Thousand Oaks.

Dellana, S. og Kros, J. (2018). ISO 9001 and supply chain quality in the USA. International Journal of Productivity and Performance Management, 67(2), 297-317. https://doi.org/10.1108/IJPPM-05-2015-0080

Einarsdóttir, P. J. (2020). All that Glitters is Not Gold: Shrinking and Bending Gender Equality in Rankings and Nation Branding. NORA-Nordic Journal of Feminist and Gender Research, 1-13. https://doi.org/10.1080/0 8038740.2020.1745884

Esterberg, K. G. (2002). Qualitative methods in social research. McGraw-Hill.

Forsætisráðuneytið. (2020). Jafnrétti 2020, skýrsla forsætisráðherra um jafnréttismál 2018-2019, Stjórnarráð Íslands. https://www.stjornarradid.is/lisalib/getfile.aspx?itemid=7f13c41c-5323-11ea-9455-005056bc530c

Gerða Björg Hafsteinsdóttir, Erla Sólveig Kristjánsdóttir og Póra H. Christiansen. (2020). Petta er allt mannanna verk: Upplifun stjórnenda á áhrifum jafnlaunavottunar á kjaraumhverfi. Stjórnmál og Stjórnsýsla, 16(2), 261-284. https://doi.org/10.13177/irpa.a.2020.16.2.9

Gorman, G. E. og Clayton, P. (2005). Qualitative research for the information professional: a practical handbook (2. útg.). Facet Publishing. 
Grimsdottir, E. og Edvardsson, I. R. (2018). Knowledge management, knowledge creation, and open innovation in Icelandic SMEs. Sage Open, 1-13. https://doi.org/10.1177/2158244018807320

Guðbjörg Ingunn Óskarsdóttir. (2019). „Pú parft að vera með skjölunina í lagi - pað er bara númer eitt, tvö og prjú“: Innleiðing jafnlaunastaðals hjá skipulagsheildum. MIS-ritgerð í upplýsingafræði, Háskóli Íslands.

Gunnlaugsdottir, J. (2012). Information and records management: A precondition for a well functioning quality management system. Records Management Journal, 22(3), 170-185. https://doi.org/10.1108/09565691211283138

Hagstofa Íslands. (2018). Launamunur kynjanna dregst saman. https://hagstofa.is/utgafur/frettasafn/laun-ogtekjur/rannsokn-a-launamun-kynjanna-2008-2016/

Hagstofa Íslands. (2020). Brautskráningar á háskólastigi og doktorsstigi eftir kyni [Talnaefni]. https://hagstofa. is/talnaefni/samfelag/menntun/haskolastig/

Halldór Benjamín Porbergsson. (2017). Umsögn um breytingu á lögum nr. 10/2008, um jafna stöðu og jafnan rétt kvenna og karla, pskj. 570, 437. mál. Alpingi. https://www.althingi.is/altext/erindi/146/146-1359.pdf.

Haraldsdottir, R. K. og Gunnlaugsdottir, J. (2018). The missing link in information and records management: Personal knowledge registration, Records Management Journal, 28(1), 79-98. https://doi.org/10.1108/RMJ-052017-0013

Haraldsdottir, R. K., Gunnlaugsdottir, J., Hvannberg, E. T. og Christensen, P. H. (2018). Registration, access and use of personal knowledge in organizations. International Journal of Information Management, 40, 8-16. https://doi.org/10.1016/j.ijinfomgt.2018.01.004

Haraldsdottir, R. K. (2020). „Award-winning organizations: How Outstanding organizations manage the registration, access and use of the knowledge of employees." Electronic Journal of Knowledge Management, 18(2), 91-173. https://doi.org/10.34190/EJKM.18.02.001

Heiðrún Björk Gísladóttir. (2020). Umsögn Samtaka atvinnulífsins um frumvarpið. https://samradsgatt.island. is/oll-mal/\$Cases/Details/?id=2715\#advices

Helgi Pór Ingason. (2015). Gæðastjórnun. Samræmi, samhljómur og skipulag. JPV útgáfa.

Helgi Tómasson. (2017). Umsögn um lagafrumvarp, 437. mál, 146. löggjafarping: Jafnlaunavottun. Alpingi. https:// www.althingi.is/altext/erindi/146/146-1258.pdf

Henttonen, P. og Kettunen, K. (2011). Fuctional classification of records and organisational structure. Records Management Journal, 21(2), 86-103. https://doi.org/10.1108/09565691111152035

Ivanova, A., Gray, J. og Sinha, K. (2014). Towards a unifying theory of management standard implementation. International Journal of Operations E Production Management, 34(10), 1269-1306. https://doi.org/10.1108/ IJOPM-03-2013-0117

ÍST ISO 15489-1: 2016: Upplýsingar og skjalfesting - skjalastjórn. 1. hluti: Hugmyndir og meginreglur (2. útg.). (2018). Staðlaráð Íslands.

ÍST 85:2012 Jafnlaunakerfi - kröfur og leiðbeiningar. (2012). Staðlaráð Íslands.

Jafnréttisstofa. (2021). Listi yfir aðila sem hlotið hafa vottun. https://www.jafnretti.is/is/vinnumarkadur/jofn-launog-jafnir-moguleikar/listi-yfir-adila-sem-hlotid-hafa-vottun

Jóhanna Gunnlaugsdóttir. (2003). Gildi skjalastjórnar fyrir gæðastjórnun: Könnun meðal ISO 9000 vottaðra fyrirtækja á Íslandi, Í Friðrik H. Jónsson (ritstj.), Rannsóknir í félagsvísindum IV, bls. 35-49. Reykjavík: Félagsvísindastofnun Háskóla Íslands.

Jóhanna Gunnlaugsdóttir. (2010). Vottað gæðakerfi: Hvatar og áskoranir, Í Gunnar Pór Jóhannesson og Helga Björnsdóttir (ritstj.), Rannsóknir í félagsvísindum XI: Félags- og mannvísindadeild, 135-148. Reykjavík: Félagsvísindastofnun Háskóla Íslands.

Jóhanna Gunnlaugsdóttir og Árni Jóhannsson. (2013). Vistun skjala og upplýsinga sem verða til við fjarvinnu hjá eftirlitsstofnunum ríkisins, fjóðarspegillinn XIV: Rannsóknir í félagsvísindum - Félags- og mannvísindadeild, 1-9. Reykjavík: Félagsvísindastofnun Háskóla Íslands.

Jóhanna Gunnlaugsdóttir og Ragna Kemp Haraldsdóttir. (2015). Upplýsinga- og skjalastjórn - krafa samtímans. Viðskiptablaðið, 22(10), 23. http://vb.is/skodun/upplysinga-og-skjalastjorn-krafa-samtimans/123142/

Jóhanna Rósa Arnardóttir og Jón Torfi Jónasson. (2004). Gildi menntunar í lífi fullorðins fólks. Tímarit um menntarannsóknir, 129-143.

Kakouris, A. og Sfakianaki, E. (2019). Motives for implementing ISO 9000 - does enterprise size matter? International Journal of Productivity and Performance Management, 68(2), 447-463. https://doi.org/10.1108/IJPPM-03-2018-0096

Katrín Björg Ríkharðsdóttir og Jón Fannar Kolbeinsson. (2020). Umsögn vegna frumvarps til laga jafna stöðu og jafnan rétt kynjanna. file://C:/Users/rh/AppData/Local/Temp/Ums\%C3\%B6gn\%20jafnr\%C3\%A9ttisstofu\%20J\%C3\%B6fn\%20sta\%C3\%B0a\%20og\%20jafn\%20r\%C3\%A9ttur\%20kynjanna-2.pdf

Katrín Ólafsdóttir og Steinunn Rögnvaldsdóttir. (2015). Staða kvenna og karla á íslenskum vinnumarkaði. Velferðarráðuneytið.

Katrín Ólafsdóttir. (2018). Iceland is the best, but still not equal, Søkelys på arbeidslivet, 111-126. https://doi. org/10.18261/issn.1504-7989-2018-01-02-07

Kerzner, H. R. (2009). Project management: a systems approach to planning, scheduling, and controlling (10. útg.). New York: John Wiley \& Sons.

Kim, D.-Y., Kumar, V. og Kumar, U. (2011). A performance realization framework for implementing ISO 9000. 
International Journal of Quality $\mathcal{E}$ Reliability Management, 28(4), 383-404. https://doi.org/10.1108/ 02656711111121807

Kvale, S. og Brinkman, S. (2009). Interviews: Learning the craft of qualitative research interviewing. Thousand Oaks: Sage.

Lederman, P. F. (2012). Getting buy-in for your information governance program. Information Management Journal, 4(46), 34-37.

Lemieux, V. (1996). The use of total quality management in a records management environment. Records Management Quarterly, 30(3), 28-38.

Lin, C. og Jang, W. (2008). Successful ISO 9000 implementation in Taiwan. International Journal of Productivity and Performance Management, 57(8), 600-622. https://doi.org/10.1108/17410400810916044

Lindahl, B. (2019). Nordic Power Positions: A Modest Increase in Gender Equality. Nordic Labour Journal. $\quad$ http://www.nordiclabourjournal.org/i-fokus/in-focus-2019/gender-equality-barometre-2019/article.2019-03-04.2406255703

Lög um faggildingu o.fl. nr. 24 (2006).

Lög um jafna stöðu og jafnan rétt kynjanna nr. 150 (2021).

Lög um jafna stöðu og jafnan rétt kvenna og karla nr. 10 (2008).

Lög um opinber skjalasöfn nr. 77 (2014).

Lög um persónuvernd og meðferð persónuupplýsinga nr. 90 (2018).

Makinen, S. og Henttonen, P. (2011). Motivations for records management in mobile work. Records Management Journal, 21(3), 188-204. https://doi.org/10.1108/09565691111186867

Morgunblaðið. (2019, 2. nóvember). Prjú af 56 hafa fengið vottun. Morgunblaðið. https://www.mbl.is/frettir/innlent/2019/11/02/thrju_af_56_hafa_fengid_vottun/

Ólafur Stephensen. (2017). Umsögn um frumvarp til laga um breytingu á lögum um jafna stöðu og jafnan rétt kvenna og karla, nr. 10/2008, með síðari breytingum (jafnlaunavottun), 437. mál 146. löggjafarpings. Alpingi. https://www.althingi.is/altext/erindi/146/146-1238.pdf

Ólöf Júlíusdóttir, Guðbjörg Linda Rafnsdóttir og Porgerður Einarsdóttir. (2018). Top managers and the gendered interplay of organizations and family life: The case of Iceland. Gender in Management: An International Journal, 33(8), 602-622. https://doi.org/10.1108/GM-03-2017-0028

Ólöf Júlíusdóttir. (2019). Tíminn, ástin og fyrirtækjamenning: Valdaójafnvægi kvenna og karla í stjórnendastöðum í íslensku efnahagslífi [doktorsritgerð]. Háskóli Îslands: Háskólaútgáfan.

Ómar Friðriksson. (2019, 2. nóvember). 26\% sveitarfélaga hafa uppfyllt kröfur. Morgunblaðið.

Prior, L. (2011). Using documents in social research. Í D. Silverman (ritstj.), Qualitative research (3. útg.), bls. 93-110. Sage.

PwC. (e.d.). Ráðgjöf við uppsetningu jafnlaunakerfis. https://www.pwc.is/is/thjonusta/rannsoknir_og_ greiningar/jafnlaunavottun.html

Ragnhildur Prastardóttir. (2019, 7. janúar). Stjórnarráðið án jafnlaunavottunar. Morgunblaðið.

Ragna Kemp Haraldsdóttir. (2018). Að loka markinu - um öryggi gagna. Viðskiptablaðið. http://www.vb.is/ skodun/ad-loka-markinu-um-oryggi-gagna/148082/

Saffady, W. (2016). Records and information management: Fundamentals of professional practice. Overland Park: ARMA International.

Samtök atvinnulífsins. (e.d.). Menntun í fyrirtækjum. https://sa.is/samkeppnishaefni/menntamal/menntun-ifyrirtaekjum

Sigala, M. og Chalkiti, K. (2007). Improving performance through tacit knowledge externalisation and utilisation: Preliminary findings from Greek hotels, International Journal of Productivity and Performance Management, 56(5), 456-483. https://doi.org/10.1108/17410400710757141

Sigala, M. og Chalkiti, K. (2014). Investigating the exploitation of web 2.0 for knowledge managment in the Greek tourism industry: An utilisation-importance analysis, Computers in Human Behavior, 30, 800-812. https://doi.org/10.1016/j.chb.2013.05.032

Sigurður Hannesson. (2019, 2. janúar). Menntun í takt við tímann. https://www.si.is/upplysingar-og-utgafa/ greinasafn/menntun-i-takt-vid-timann\#

Silverman, D. (2017). Doing Qualitative Research. Sage.

Sigmarsdottir, S. (2018). Once more, Iceland has shown it is the best place in the world to be female. The Guardian. https://www.theguardian.com/commentisfree/2018/jan/05/iceland-female-women-equal-pay-gender-equality

Sigríður Halldórsdóttir. (2013). Inngangur að aðferðarfræði. Í Sigríður Halldórsdóttir (ritstj.), Handbók í aðferðafræði rannsókna, bls. 17-30. Háskólinn á Akureyri.

Staðlaráð Íslands. (2008). Vinnubók fyrir pjónustufyrirtæki. Reykjavík.

Staðlaráð Íslands. (2020). Staðlar og löggjöf. Staðlaráð Íslands. https://www.stadlar.is/library/Skrar/stadlarad_ stadlar_og_loggjof_2020.pdf

Stjórnarrád Íslands. (e.d.a). Jafnlaunavottun. Algengar spurningar. https://www.stjornarradid.is/default.aspx?PageID=eb09831c-9c28-11e6-9409-005056bc4d74

Stjórnarrád Íslands. (e.d.b). Jafnlaunavottun. Forsaga. https://www.stjornarradid.is/default.aspx?PageID=2aa2a65f-9c28-11e6-9409-005056bc4d74 
Stjórnarráð Íslands. (2018). Verkefni. Rýmri tímafrestur fyrirtækja og stofnana til að öðlast jafnlaunavottun. https:// www.stjornarradid.is/verkefni/allar-frettir/frett/2018/09/28/Rymri-timafrestur-fyrirtaekja-og-stofnana-til-ad-odlast-jafnlaunavottun/

Stjórnarráð Íslands. (2019). Staða jafnlaunavottunar. https://www.stjornarradid.is/efst-a-baugi/frettir/stokfrett/2019/05/10/Stada-jafnlaunavottunar/

Stjórnarráð Íslands. (2020). 134 fyrirtæki og stofnanir komin með jafnlaunavottun. https://www.stjornarradid.is/ efst-a-baugi/frettir/stok-frett/2020/01/02/134-fyrirtaeki-og-stofnanir-komin-med-jafnlaunavottun/

Stjórnarráð Íslands. (2021a). Ísland i efsta sæti Alpjóðaefnahagsráðsins um kynjajafnrétti tólfta árið i röð. https:// www.stjornarradid.is/efst-a-baugi/frettir/stok-frett/2021/03/31/Island-i-efsta-saeti-Althjodaefnahagsradsins-um-kynjajafnretti-tolfta-arid-i-rod/

Stjórnarráð Islands. (2021b). Staða jafnlaunavottunar í árslok 2020. https://www.stjornarradid.is/efst-a-baugi/ frettir/stok-frett/2021/01/13/Stada-jafnlaunavottunar-i-arslok-2020/

Stjórnarráð Íslands. (2021c). Tekjusagan uppfærð: Háskólamenntaðar konur með svipaðar tekjur og karlar með grunnmenntun. https://www.stjornarradid.is/efst-a-baugi/frettir/stok-frett/2021/02/17/Tekjusagan-uppfaerd-Haskolamenntadar-konur-med-svipadar-tekjur-og-karlar-med-grunnmenntun/

Tarí, J. J., Molina-Azorín, J. F. og Heras, I. (2012). Benefits of the ISO 9001 and ISO 14001 standards: A literature review. Journal of Industrial Engineering and Management, 5(2). http://dx.doi.org/10.3926/jiem.488

Taylor, S. J., Bogdan, R. og DeVault, M. L. (2016). Introduction to qualitative research methods: A guidebook and resource. Wiley.

Thunnissen, M., Boselie, P. og Frutyier, B. (2013). A review of talent management: Infancy or adolescence?, The International Journal of Human Resource Management, 24(9), 1744-1761. https://doi.org/10.1080/09585192 .2013 .777543

Unnur Ýr Kristjánsdóttir. (2017). Gender Equity through Equal Pay: Iceland Customs take the Lead. https:// mag.wcoomd.org/uploads/2018/05/OMDActu83_UK_web-.pdf

Velferðarráðuneytið. (2018). Skýrsla félags- og jafnréttismálaráðherra um stöđu og próun jafnréttismála 2015-2017. https://www.stjornarradid.is/lisalib/getfile.aspx?itemid=33cbc9c1-217e-11e8-9429-005056bc530c

VR. (e.d.). Jafnlaunastaðall. https://www.vr.is/um-vr/jafnretti/jafnlaunastadall/

Wagner, I. (2018). Certified Equality: The Icelandic Equal pay Standard. Institute for Social Research. Report 2018:11. https://www.researchgate.net/publication/329371051_Certified_Equality_The_Icelandic_Equal_ Pay_Standard/link/5c052f50299bf169ae2e4b2a/download

Wagner, I. (2020). Equal Pay for Work of Equal Value? Iceland and the Equal Pay Standard. Social Politics: International Studies in Gender, State E Society, jxaa032, 1-20. https://doi.org/10.1093/sp/jxaa032

Viðskiptaráð, Kauphöll Íslands og Samtök atvinnulífsins. (2021). Leiðbeiningar - Stjórnarhættir fyrirtækja (6. útg.). https://leidbeiningar.is/leidbeiningar

World Economic Forum. (2021). Global Gender Gap Report 2021. Genf: World Economic Forum. http://www3. weforum.org/docs/WEF_GGGR_2021.pdf

Zheng, T. (2017). A Literature Review on Knowledge Sharing, Open Journal of Social Sciences, 5, 51-58. https:// doi.org/10.4236/jss.2017.53006

Porvaldur S. Helgason. (2021, 30. mars). Kynjajafnrétti mest á Íslandi tólfta árið í röð en „gríðarlegt verk óunnið“. Fréttablaðið. https://www.frettabladid.is/frettir/kynjajafnretti-mest-a-islandi-tolfta-arid-i-rod-engridarlegt-verk-ounnid/

Póra H. Christiansen, Ásta Dís Óladóttir, Erla S. Kjartansdóttir og Sigrún Gunnarsdóttir. (2021). Forstjóraráðningar í pjóðhagslega mikilvægum fyrirtækjum: Kynjahalli, útilokun og ófagleg ráðningarferli? Stjórnmál og Stjórnsýsla, 17(1), 107-129. file:///C:/Users/rh/AppData/Local/Temp/3386-5770-1-PB-1.pdf

Pskj. 14, 14. mál, 151. löggjafarping 2020-2021. https://www.althingi.is/thingstorf/thingmalin/erindi/?ltg=$151 \& \mathrm{mnr}=14$

Öll erindi í 437. máli 146. löggjafarpings: jöfn staða og jafn réttur kvenna og karla (jafnlaunavottun). https:// www.althingi.is/thingstorf/thingmalin/erindi/?ltg=146\&mnr=437 
